Working Paper in Economics No. 712

\title{
Nudging to reduce meat consumption: Immediate and persistent effects of an intervention at a university restaurant
}

\section{Verena Kurz}

Department of Economics, November 2017 


\title{
Nudging to reduce meat consumption: Immediate and persistent effects of an intervention at a university restaurant ${ }^{*}$
}

\author{
Verena Kurz ${ }^{\ddagger}$
}

November 6, 2017

\begin{abstract}
Changing dietary habits to reduce the consumption of meat is considered to have great potential to mitigate food-related greenhouse gas (GHG) emissions. To test if nudging can increase the consumption of vegetarian food, I conducted a field experiment with two university restaurants. At the treated restaurant, the salience of the vegetarian option was increased by changing the menu order, and by placing the dish at a spot visible to customers. The other restaurant served as a control. Daily sales data on the three main dishes sold were collected from September 2015 until June 2016. The experiment was divided into a baseline, an intervention, and a reversal period where the setup was returned to its original state. Results show that the nudge increased the share of vegetarian lunches sold by around 6 percentage points. The change in behavior is partly persistent, as the share of vegetarian lunches sold remained 4 percentage points higher than during the baseline period after the original setup was reinstated. The changes in consumption reduced GHG emissions from food sales around 5 percent.
\end{abstract}

Keywords: nudging, field experiment, meat consumption, climate change mitigation

JEL classification: D12, C93, Q50, D03

\footnotetext{
* I thank Eurest Restaurants at Gothenburg University, especially Krister Johansson, Harald Boye, and Mikael Börjesson, for facilitating this field experiment and providing the data. Many thanks to Randi Hjalmarsson, Fredrik Carlsson, Nadine Ketel, Gerlinde Fellner-Röhling, Simon Felgendreher, seminar participants at the University of Gothenburg, and participants at the 2016 Nordic Conference in Behavioral and Experimental Economics in Oslo and the 2016 Advances with Field Experiments Conference in Chicago for helpful comments. Any remaining errors are my own. Financial support from the Swedish Environmental Protection Agency is gratefully acknowledged.

†Department of Economics, University of Gothenburg, Sweden, verena.kurz@economics.gu.se.
} 


\section{Introduction}

This paper presents results from a field experiment using a nudge with the aim of increasing the share of vegetarian lunches sold at a university restaurant. Changing diets to reduce consumption of meat and dairy is seen as an important part of mitigation efforts to reach a 2degree climate target (Bryngelsson et al., 2016; Girod et al., 2014). The livestock sector contributes approximately 14.5 percent of global human-induced greenhouse gas (GHG) emissions yearly (Gerber et al., 2013), and meat consumption is causing about one-third of foodrelated GHG emissions emerging from consumption in Western countries such as Sweden and the United States (Jones and Kammen, 2011; Naturvårdsverket, 2011). ${ }^{1}$ Reducing meat consumption is also seen as a way to protect biodiversity, land, and freshwater ecosystems (Machovina and Feeley, 2014; Pelletier and Tyedmers, 2010; Pimentel and Pimentel, 2003). Moreover, a reduction in meat consumption can yield significant benefits for both public health and the environment (Springmann et al., 2016; Tilman and Clark, 2014; Westhoek et al., 2014), mainly by decreasing the risk of colorectal cancer, type 2 diabetes, and cardiovascular diseases (Swedish National Food Agency, 2015).

However, as data from Sweden where this field experiment took place, shows, reducing meat consumption will be challenging: per capita consumption has constantly risen since the 1990s to a record-high 87.7 kilograms (kg) per person in 2016 (Swedish Agricultural Board, 2017). Under the absence of price instruments such as meat taxes, one suggestion gaining popularity in the literature is to use nudging as a cheap and nondistortionary strategy to change consumer behavior towards less carbon-intensive consumption patterns (Girod et al., 2014; Lehner et al., 2016; Sunstein, 2015). ${ }^{2}$ A nudge is commonly understood as a soft push toward behavior that is judged to be desirable by individuals or policy makers but that has not been fully adopted. Such a soft push can be implemented through small changes in the decision environment, while prices and the choice set remain unchanged (Thaler and Sunstein, 2008). Most nudges build on a dual process model of cognition, which models human behav-

\footnotetext{
${ }^{1}$ In general, food is responsible for around one-fourth of the consumption-based emissions of an average US household. For Sweden, emissions from consumption are available not on a household but on an individual basis: approximately 8 tons of $\mathrm{CO}_{2}$ equivalent $\left(\mathrm{tCO}_{2} \mathrm{e}\right)$ per capita emerge from private consumption, of which 2 $\mathrm{tCO}_{2} \mathrm{e}$ relate to food. Of those, $0.7 \mathrm{tCO}_{2} \mathrm{e}$ can be attributed to meat consumption (Naturvårdsverket, 2011).

${ }^{2}$ Alternative policy instruments such as food consumption taxes based on GHG emissions have been discussed by the scientific community, but implementation is not foreseeable yet (Säll and Gren, 2015; Wirsenius et al., 2011). Carbon labeling has also been discussed as a possibility to reduce meat consumption. See Shewmake et al. (2015) for a theoretical analysis and Visschers and Siegrist (2015) and Vlaeminck et al. (2014) for empirical tests.
} 
ior as governed by two modes of thinking and deciding (Kahneman, 2003, 2011). Decisions dominated by the first mode, also called system one, are characterized by an intuitive, fast, and automatic style of thinking where cognitive effort is low. In the second mode, or system two, slow, reflective, and controlled processes, which require more cognitive effort, dominate. Nudging often targets decisions dominated by system one, where cognitive effort is low and the decision environment is of high importance. Food choices are seen as classical examples of decisions governed by system one where the choice environment, such as the salience of items, the structure of food assortments, or the packaging, matters (Cohen and Farley, 2007; Marteau et al., 2012; Wansink and Sobal, 2007). In this experiment, I test whether nudging can reduce meat consumption during lunch by altering two aspects of a restaurant's physical environment: the order in which the dishes are presented on the menu and the visibility of the vegetarian dish. Moreover, I analyze the effect of the nudge on consumption choices over time and test whether the nudge has any persistent effects after the intervention ends.

To date, few field experiments have actually tested the efficacy of nudging to reduce environmental impacts from consumption. Examples include the use of social norms to reduce household water and electricity consumption (Allcott, 2011; Ferraro and Price, 2013; Jaime Torres and Carlsson, 2016) and changing the default setting of office printers to duplex to reduce paper consumption (Egebark and Ekström, 2016). The evidence for nudging as a tool to facilitate healthier food choices is broader and mostly comes from experiments changing aspects of the physical environment, such as the menu order or the convenience of ordering unhealthy items (Dayan and Bar-Hillel, 2011; Just, 2009; Rozin et al., 2011; Wisdom et al., 2010). However, there is no evidence as to whether nudging also works to induce more environmentally friendly food choices. Conceptually, nudging for the environment may be very different from nudging for health: while nudging healthy choices is often motivated by the idea of inconsistent individual preferences such as present bias, which causes people to choose unhealthy options in the present that they will regret in the future (see, for example, Wisdom et al., 2010), it is not clear that such cognitive biases exist with respect to the sustainability of food choices. With regard to the high observed levels of meat consumption, it could well be that people's preferences are coherent, reducing the potential of nudging as a strategy to change choices. Another aspect that can reduce the effect nudging has on choices are strong underlying preferences for the good that the nudge is intended to reduce consumption of. For example, Wansink and Just (2016) find that children opted out from the default option of apples as a side dish and chose French fries. Wijk et al. (2016) find that increasing the accessibility of whole grain bread compared to white bread did not increase its sales. 
There is some suggestive evidence that Swedes would like to reduce their meat consumption but fail to do so. In a representative World Wildlife Fund (WWF) survey, 37 percent of the respondents state that they will cut their meat consumption in order to reduce their climate impact during the coming year, and 33 percent state that they have already done so during the previous year (WWF, 2016). At the same time, Swedish meat consumption rose to an all-time high in 2016 (Swedish Agricultural Board, 2017). Whether preferences for meat are simply too strong for nudging to help overcome a potential intentions-behavior gap is thus an important question to examine.

The experiment took place at two university restaurants in Gothenburg, Sweden, with one serving as the treated restaurant and the other as a control. Both are run by the same provider and serve three warm dishes during lunch, one vegetarian and two containing either meat or fish. Daily sales data on the number of each of the three main dishes sold were collected from September 2015 until June 2016, covering the whole academic year. The first nine weeks served as a baseline period, followed by an intervention period of 17 weeks at the treated restaurant, where the vegetarian option was moved from the middle to the top of the printed menu, and the dish was moved from behind the counter to a spot visible to customers at the point of decision-making. Thus both the menu order and the visibility of the vegetarian dish were changed simultaneously. However, we have some evidence for the effect of changing the menu order only, as the local chef changed the menu order for five nonconsecutive weeks during spring 2016 at the control restaurant. During the final 13 weeks of the year, the original setup was reinstated at the treated restaurant.

Previous experiments have focused on the immediate impacts of nudges on food consumption, but it is important to study longer time periods to evaluate their overall effect. ${ }^{3}$ One concern with nudging is that it might have only short-term effects that quickly disappear once people gain experience with the good or the choice setting (Croson and Treich, 2014; Löfgren et al., 2012; Lusk, 2014). In the present experiment, this could be the case if customers were initially nudged to choose the vegetarian option but returned to their original choices once they became accustomed to the new setting, either because they did not like the vegetarian

\footnotetext{
${ }^{3}$ Previous experiments on food nudges (for example, Dayan and Bar-Hillel , 2011; Just, 2009; Rozin et al., 2011; Wisdom et al., 2010) mainly were conducted in places that customers were not expected to visit repeatedly, such as diners or hotels; in other cases (for example, Policastro et al., 2015), the intervention was done too infrequently to analyze effects over time.
} 
option or because the nudge initially increased the number of ordering mistakes. ${ }^{4}$ The effect of the nudge could also increase over time, such as if people recommend eating vegetarian to fellow students after trying it as a result of the nudge. A priori, it is not clear whether and how the impact of the nudge changes over time. Combining an intervention period of 17 weeks and a customer pool that can be assumed to be fairly constant throughout the academic year, this is the first experiment that allows for studying the effects of a food nudge over time.

Another important question is whether the nudge affects choices only during the intervention period or has a persistent impact on behavior after it is removed. To date, no studies have looked at the habit-forming effects of nudges in the food domain. ${ }^{5}$ If present utility of consuming a good depends on past levels of consumption, such as in the habit formation models of Becker and Murphy (1988) or Naik and Moore (1996), an initial increase of vegetarian lunches sold because of the nudge can lead to subsequent further increases. Empirical studies show habit formation for a range of foods (see Daunfeldt et al., 2011, for an overview), but results from experiments using incentives to increase healthier food choices are inconclusive. Consuption of targeted items is usually somewhat higher immediately after the end of an intervention than prior to it (Just and Price, 2013; List and Samek, 2015, 2017). Loewenstein et al. (2016) even find a persistent effect one and three months after the end of an incentive scheme, while Just and Price (2013) and Belot et al. (2015) do not find any persistent effects of incentives in the medium run. Nudging could be a more promising approach to creating new habits than incentivizing choices, as it does not carry the risk of crowding out intrinsic motivation (Gneezy et al., 2011). On the other hand, habit formation could be even less pronounced when using nudging, as a subtle intervention targeting the decision environment might be less successful in causing behavior change in the first place. To examine if any effect of the nudge persisted after removing it, the original setup at the treated restaurant was reinstated for the last 13 weeks of the academic year.

Results show that when using a difference-in-differences approach to estimate the treatment effect, the combined nudge of changing visibility and menu order increased the average

\footnotetext{
${ }^{4}$ This could occur if people simply point toward the dish that is most visible and assume it is the usual meat or fish dish served, or if they read off the first item on the menu. In an international environment such as the University of Gothenburg, with many foreign employees and students that do not speak Swedish, simply reading off the first item on the menu could be a reasonable strategy if this had been successful in the past. Although an English menu is also provided, the Swedish menu is the one that features most prominently in the restaurants.

${ }^{5}$ Persistent effects of behavioral interventions on water and electricity consumption have been found by studies such as Ferraro et al. (2011) and Allcott and Rogers (2014). However, as Brandon et al. (2017) discuss, these long-term effects are most likely due to an adjustment of physical capital.
} 
sales share of vegetarian lunches by around 6 percentage points during the intervention period. Analyzing the treatment effect over time shows an increase over the course of the intervention, suggesting that the average effect is not due to initial ordering mistakes or a one-off effect of trying vegetarian food. Rather, it seems as if customers learn about the vegetarian option, and some then incorporate it permanently into their choice set. Support for this argument also comes from the postintervention period, when the original setup was reinstated and the share of vegetarian lunches sold persisted in being 4 percentage points higher than before the intervention. Back-of-the-envelope calculations of the effect of the intervention on GHG emissions show that the nudge decreased total emissions by around 5 percent.

\section{The experiment}

\subsection{Experimental design}

The experimental design targets the visibility of the vegetarian dish and the menu order, two features of the food environment that have been shown to matter for food choice. Changing the visibility can affect whether and how prominently a dish features in the consideration set (Wansink and Love, 2014). If customers might not even consider the vegetarian dish an option and routinely choose between the two meat dishes offered, making it visible can add it to the consideration set without changing what is offered. Enhanced visibility will also increase a dish's saliency - that is, how much it attracts attention and how prominently it features in decision-making (Cohen and Farley, 2007; Wansink and Sobal, 2007). Third, changing which dish is visible at the point of purchasing can also change the customers' information about a dish. If vegetarian dishes are unknown by name to a majority of consumers, making the dish visible can help them evaluate the vegetarian option before making a choice.

Changing the order in which the three lunch options are presented on the menu relies on findings from previous research showing that when people are choosing from a list, order effects can bias them toward selecting specific objects with a higher likelihood. Primacy effects increase the likelihood that they will choose items listed first. Such effects can arise if people exhibit a confirmatory bias, such as looking for reasons to choose an alternative rather than for reasons not to choose it, because of growing fatigue when reading through a list, or as a result of satisficing behavior, where options are evaluated as generally similar and reading through a whole list entails higher costs than benefits (Carney and Banaji, 2012; Mantonakis et al., 2009; Miller and Krosnick, 1998). Dayan and Bar-Hillel (2011) study the influence of menu order on choices in a coffee shop and find that placing an item at one of the extreme 
positions (top or bottom) increases its sales by approximately 20 percent compared with when the same item appears in the middle. Policastro et al. (2015) study the order of an ingredients list on an ordering form and find that putting healthy items at the top of each ingredient category leads to healthier self-assembled sandwiches. ${ }^{6}$

The experiment was conducted at two restaurants at the University of Gothenburg during the academic year 2015-16. Gothenburg is the second largest city in Sweden, with a population around 550,000, and its university is the fourth largest in the country, with about 24,000 full-time students. The departments of the university are spread across the city, and the university buildings that hosted the experiment are approximately 2.5 kilometers $(\mathrm{km})$ away from each other. Both restaurants serve three warm alternatives during lunch: one vegetarian and two including either meat or fish (called "meat 1 " and "meat 2 " in the following). ${ }^{7}$ The restaurants are subject to the same management, but the local chefs decide on the weekly menus, and hence they differ across restaurants. Prices, however, are the same: warm dishes cost 70 SEK (approximately $€ 7.30$ or US\$7.80) and are accompanied by bread, salad, and water. Instead of a warm dish, customers can also opt for soup, various salads, or sandwiches, which are priced differently. At both restaurants, the menu for the whole week is posted at the entrance but only the daily menu is shown at the point of ordering. Many employees and students also subscribe to the restaurant's weekly menu by email.

Restaurant 1, the treated restaurant where the nudge was implemented, is in a building that houses the economics, business administration, and law faculty. Hence, students and faculty members eating there mainly belong to those disciplines. Restaurant 2, which serves as a control where no changes were undertaken, is in a building housing mostly institutions belonging to the humanities. To capture initial differences between the restaurants in the quantity of vegetarian food consumed, the academic year was divided into three experimental periods. Period 0, the baseline or control period, lasted from September 1 until November 8 (10 weeks). The intervention period (period 1) lasted from November 9 until March 6 (17 weeks including Christmas break). From March 7 until June 3 (13 weeks), the intervention ended at the treated restaurant and the original setup was restored (period 2, or reversal period). ${ }^{8}$

\footnotetext{
${ }^{6}$ In addition, they increased the healthy items' saliency by adding visual cues, such as stars and bold print.

${ }^{7}$ The two nonvegetarian dishes are called dagens husman ("traditional Swedish") and gränslöst gott ("limitless good"), indicating that the style of the dishes is different. However, a detailed analysis of the menus reveals that about one-third of the dishes served show up as both the "traditional Swedish" and "limitless good" dish.

${ }^{8}$ The final sample, as described in the data section, contains 10 weeks of data for the baseline period, 14 weeks of data for the intervention period, and 12 weeks of data for the reversal period.
} 
The experimental design is summarized in Table 1. During the baseline period, the restaurants differed in terms of menu layout and visibility of the dishes at the point where customers made their decision about which dish to choose for lunch. Concerning the menu order, the vegetarian option was found in the second position at the treated restaurant, framed by the two meat options. In the control restaurant, the vegetarian dish was listed first. The restaurants also differed with respect to which dish was visible at the point of ordering. At the treated restaurant, only one of the three dishes can be kept before the counter and is visible to the customers when they place their order. Before the intervention, this was the dish that was also shown at the top of the menu, hence a meat or fish dish. At the control restaurant, customers place their orders, pay, and then proceed to a counter where they pick up their lunches. However, the counter is fully transparent, and all three dishes are equally visible. If a customer wants to see how a dish looks before placing an order, he or she can easily go and take a look. From comparing the setup at each of the two restaurants during the pre-experimental period, one can conclude that the control restaurant's food environment is more favorable for choosing the vegetarian option.

Table 1. Summary of the food environment across restaurants and treatment periods

\begin{tabular}{llll}
\hline \hline & & \multicolumn{1}{c}{ Treated restaurant } & \multicolumn{1}{c}{ Control restaurant } \\
\hline \multirow{4}{*}{ Menu order } & $\begin{array}{l}\text { Period 0 } \\
\text { (Baseline period) }\end{array}$ & $\begin{array}{l}\text { Position 1: Meat 1 } \\
\text { Position 2: Vegetarian } \\
\text { Position 3: Meat 2 }\end{array}$ & $\begin{array}{l}\text { Position 1: Vegetarian } \\
\text { Position 2: Meat 1 } \\
\end{array}$ \\
\cline { 2 - 4 } & Period 1 (Treatment & Position 3: Meat 2 \\
& period) & Position 1: Vegetarian & Position 1: Vegetarian \\
& Position 2: Meat 1 & Position 2: Meat 1 \\
& Period 2 & Position 3: Meat 2 & Position 3: Meat 2 \\
\hline \multirow{3}{*}{ Visibility } & Position 1: Meat 1 & Position 1: Vegetarian or Meat 1 \\
& Peversal period) & Position 2: Vegetarian & Position 2: Vegetarian or Meat 1 \\
& Position 3: Meat 2 & Position 3: Meat 2 \\
\cline { 2 - 4 } & Period 1 & Meat 1 dish & All three equally visible \\
\cline { 2 - 4 } & Period 2 & Vegetarian dish & All three equally visible \\
\hline \hline
\end{tabular}

During the treatment period, the vegetarian dish was moved on both the weekly and the daily menus from position two to the top at the treated restaurant (see appendix Figure A.1 for examples of the menus during period 0 and period 1 at the treated restaurant). Moreover, it was made visible by placing it before the counter at the point of ordering, and consequently both meat dishes were placed behind the counter.

At the control restaurant, no changes in menu order or visibility were made during the control or treatment period. However, on February 1, 2016 (14 weeks into period 1), the chefs changed at both restaurants. The chef of the control restaurant moved to the treated restaurant, and a new chef from outside the organization was employed at the control restaurant. Implica- 
tions of this change in staff for identification of the treatment effect are discussed in the methodology section.

For the remaining 13 weeks of the semester, the setup at the treated restaurant was returned to its original state: the vegetarian dish was again placed in the middle of the menu, and a meat dish was put before the counter. At the control restaurant, the new chef independently introduced some changes in operations. Amongst others, he switched the menu order during five nonconsecutive weeks of period 2, moving the vegetarian dish from the top to the middle position. This small additional natural experiment will be used to analyze the effect of an isolated change in menu order without simultaneously changing the visibility of dishes.

\subsection{Data}

Sales data on the daily number of lunches sold by category (vegetarian, meat 1 , and meat 2) and by restaurant were collected from September 1, 2015, to June 3, 2016, covering the whole Swedish academic year 2015-16. Data were collected via the electronic cash registers at the restaurants and delivered via Excel files for analysis. ${ }^{9}$ The full dataset includes 181 days for the treated restaurant and 184 days for the control restaurant. ${ }^{10}$ The analysis sample is restricted to days when all three options were offered for lunch, reducing the number of observations by three for the control restaurant. ${ }^{11}$ Moreover, either sales or menu data are missing for one day from the control and ten days from the treated restaurant. For five days in spring 2016, a different pricing scheme was applied at both restaurants, with one of the three dishes sold at a higher price. Data from these five days are excluded from the sample, as on four of those days the more expensive dish was a meat dish. The final sample used for the empirical analysis includes 175 days for the control restaurant and 166 days for the treated restaurant.

Descriptive statistics on the number of dishes sold overall and by dish type are shown in Table 2. The treated restaurant is slightly bigger than the control restaurant, selling on average 152 warm lunches a day throughout the year, while the control sells on average about 140 dishes. Total sales decrease at both restaurants throughout the year. The decrease is larger at the treated than at the control restaurant, which could be an unintended side effect of the

\footnotetext{
${ }^{9}$ The cash registers have three different buttons that were labeled with the Swedish category names of the dishes, dagens husman (meat 1), gränslöst gott (meat 2), and grönt och gott (vegetarian), minimizing the risk of mistakes in recording the type of dish correctly. An example picture of the registers is available on request.

${ }^{10}$ The number of days differs because two job fairs took place at the treated restaurant building, during which the restaurant was closed.

${ }^{11}$ During those days, which preceded public holidays, the control restaurant served only two warm dishes.
} 
nudge. To evaluate the impact of the nudge on total sales, it would be necessary to compare changes during the experiment with changes from the previous year, which is not possible because of a price increase for the warm lunch in 2014-15. According to restaurant management, the observed decrease in total sales was no larger than in previous years. ${ }^{12}$ The share of vegetarian food consumed is consistently higher at the control restaurant, which might reflect differences in the customer population, as the restaurants are located at different faculties of the university. It might also reflect the more vegetarian-friendly decision environment described above.

Table 2. Number and share of different dish types sold across the three experimental periods

\begin{tabular}{|c|c|c|c|c|c|c|c|c|}
\hline & \multicolumn{2}{|c|}{ All year } & \multicolumn{2}{|c|}{$\begin{array}{c}\text { Period } 0 \\
\text { (September- } \\
\text { November) } \\
\end{array}$} & \multicolumn{2}{|c|}{$\begin{array}{c}\text { Period } 1 \\
\text { (November- } \\
\text { March) } \\
\end{array}$} & \multicolumn{2}{|c|}{$\begin{array}{c}\text { Period 2 } \\
\text { (March-June) }\end{array}$} \\
\hline & $\begin{array}{c}\text { Average no. } \\
\text { sold / day }\end{array}$ & Share & $\begin{array}{c}\text { Average no. } \\
\text { sold / day }\end{array}$ & Share & $\begin{array}{c}\text { Average no. } \\
\text { sold / day }\end{array}$ & Share & $\begin{array}{c}\text { Average no. } \\
\text { sold / day }\end{array}$ & Share \\
\hline \multicolumn{9}{|c|}{ Treated Restaurant } \\
\hline All dishes & $\begin{array}{c}152 \\
(46.16)\end{array}$ & & $\begin{array}{c}176 \\
(62.24)\end{array}$ & & $\begin{array}{c}157 \\
(26.8)\end{array}$ & & $\begin{array}{c}125 \\
(31.09)\end{array}$ & \\
\hline Vegetarian & $\begin{array}{c}26 \\
(12.47)\end{array}$ & $\begin{array}{c}0.175 \\
(0.068)\end{array}$ & $\begin{array}{c}24 \\
(14.93)\end{array}$ & $\begin{array}{c}0.139 \\
(0.065)\end{array}$ & $\begin{array}{c}31 \\
(11.38)\end{array}$ & $\begin{array}{c}0.201 \\
(0.066)\end{array}$ & $\begin{array}{c}22 \\
(9.17)\end{array}$ & $\begin{array}{c}0.176 \\
(0.059)\end{array}$ \\
\hline Meat 1 & $\begin{array}{c}70 \\
(35.77)\end{array}$ & $\begin{array}{c}0.454 \\
(0.123)\end{array}$ & $\begin{array}{c}95 \\
(48.98)\end{array}$ & $\begin{array}{c}0.529 \\
(0.121)\end{array}$ & $\begin{array}{c}66 \\
(24.1)\end{array}$ & $\begin{array}{c}0.421 \\
(0.114)\end{array}$ & $\begin{array}{c}53 \\
(18.44)\end{array}$ & $\begin{array}{c}0.43 \\
(0.111)\end{array}$ \\
\hline Meat 2 & $\begin{array}{c}55 \\
(26.19)\end{array}$ & $\begin{array}{c}0.371 \\
(0.116)\end{array}$ & $\begin{array}{c}57 \\
(24.42)\end{array}$ & $\begin{array}{l}0.332 \\
(0.12)\end{array}$ & $\begin{array}{c}59 \\
(20.94)\end{array}$ & $\begin{array}{l}0.378 \\
(0.11)\end{array}$ & $\begin{array}{c}50 \\
(20.78)\end{array}$ & $\begin{array}{c}0.394 \\
(0.114)\end{array}$ \\
\hline Observations & \multicolumn{2}{|l|}{166} & \multicolumn{2}{|l|}{47} & \multicolumn{2}{|l|}{63} & \multicolumn{2}{|l|}{56} \\
\hline \multicolumn{9}{|c|}{ Control Restaurant } \\
\hline All dishes & $\begin{array}{c}141 \\
(21.36)\end{array}$ & & $\begin{array}{c}151 \\
(15.08)\end{array}$ & & $\begin{array}{c}142 \\
(21.02)\end{array}$ & & $\begin{array}{c}129 \\
(21.02)\end{array}$ & \\
\hline Vegetarian & $\begin{array}{c}36 \\
(11.04)\end{array}$ & $\begin{array}{c}0.258 \\
(0.066)\end{array}$ & $\begin{array}{c}40 \\
(10.31)\end{array}$ & $\begin{array}{c}0.265 \\
(0.0543)\end{array}$ & $\begin{array}{c}38 \\
(10.75)\end{array}$ & $\begin{array}{c}0.267 \\
(0.062)\end{array}$ & $\begin{array}{c}31 \\
(9.99)\end{array}$ & $\begin{array}{c}0.24 \\
(0.078)\end{array}$ \\
\hline Meat 1 & $\begin{array}{c}56 \\
(16.07)\end{array}$ & $\begin{array}{c}0.401 \\
(0.105)\end{array}$ & $\begin{array}{c}61 \\
(14.77)\end{array}$ & $\begin{array}{c}0.405 \\
(0.0977)\end{array}$ & $\begin{array}{c}53 \\
(14.02)\end{array}$ & $\begin{array}{c}0.375 \\
(0.092)\end{array}$ & $\begin{array}{c}55 \\
(18.58)\end{array}$ & $\begin{array}{c}0.43 \\
(0.12)\end{array}$ \\
\hline Meat 2 & $\begin{array}{c}48 \\
(17.19)\end{array}$ & $\begin{array}{c}0.341 \\
(0.104)\end{array}$ & $\begin{array}{c}50 \\
(17.46)\end{array}$ & $\begin{array}{c}0.329 \\
(0.112)\end{array}$ & $\begin{array}{c}51 \\
(15.53)\end{array}$ & $\begin{array}{c}0.358 \\
(0.085)\end{array}$ & $\begin{array}{c}43 \\
(18.16)\end{array}$ & $\begin{array}{c}0.329 \\
(0.116)\end{array}$ \\
\hline Observations & \multicolumn{2}{|c|}{175} & \multicolumn{2}{|l|}{49} & \multicolumn{2}{|l|}{72} & \multicolumn{2}{|l|}{54} \\
\hline
\end{tabular}

Note: Standard deviation in parentheses.

In addition to the sales data, the restaurants' menus were collected to categorize each dish by its main component. This was done to analyze whether the menu composition at the restau-

\footnotetext{
12 The decline in sales was attributed to students dropping out over the year and the fact that as students' budgets tighten throughout the year, they increasingly substitute food brought from home for restaurant food. The relatively larger decline in sales at the treated restaurant in period 2 can be due few new courses starting in business, economics, and law begin during that period, whereas during both period 0 and period 1 , many new courses start, bringing in new students that partly compensate for the dropout. At the campus where the control restaurant is located, many new courses also start during period 2.
} 
rants changed over time and to control for different dish types in the empirical analysis. Meat dishes were categorized by type of meat: beef, chicken, pork, other meat (minced meat, sausages, game, lamb), and fish. An additional category was introduced for a soup that was served as the meat 1 dish on 35 days (30 at the treated and 5 at the control restaurant), as it could be customized to be vegetarian by omitting the bacon, without this being noticed by the cashier who recorded the alternatives (meat 1 , meat 2 , or vegetarian). ${ }^{13}$ This soup is a traditional dish served on Thursdays throughout Sweden. The vegetarian dishes were categorized partly according to components included and partly by type of dish, resulting in the categories stew (such as a vegetarian curry), pasta, vegetables (for example, a vegetable gratin), patty (for example, a vegetarian burger), other vegetarian (for example, pies or omelets), vegetarian soup, ${ }^{14}$ and world (such as vegetarian enchiladas, Asian noodles, and falafel). For some types of dishes, how often they occurred on the menu varied considerably. For example, vegetarian dishes belonging to the patty category were offered on 11 percent and 13 percent of all days during periods 0 and 1, respectively, but on 27 percent of all days during period 2. Appendix Table A.1 shows how the restaurants' menu compositions changed across experimental periods for both the vegetarian and the meat dishes.

Figure 1 shows that vegetarian dishes vary in popularity depending on the dish type. For example, during the pre-experimental period, sales shares ranged from 12 percent for vegetable dishes to 21 percent for world dishes at the treated restaurant. The popularity pattern of dishes looks similar across restaurants, with patties and world dishes being most popular.

\footnotetext{
${ }^{13}$ As the soup could be customized to being vegetarian, the menu effectively contained two vegetarian and two meat dishes on the days it was served. This potentially creates measurement error in the share of vegetarian dishes sold. To minimize the impact of potential measurement error in the regressions, the soup was classified as its own category of meat dishes and entered as a control variable in the main regression specifications. Empirical results are robust to excluding the days where soup was served and are available on request.

${ }^{14}$ The vegetarian soup could also be customized to nonvegetarian by adding bacon, without this being noticed by the cashier. However, as it was served as the vegetarian dish, the menu effectively contained three meat dishes and one vegetarian dish on the days it was offered (12 days at the treated restaurant, 5 days at the control restaurant). Again, the share of vegetarian dishes sold as the variable of interest is most likely subject to measurement error on those days. Controlling for the type of dish should ameliorate the measurement error.
} 
Figure 1. Share of vegetarian dishes sold by type of dish

Treated restaurant
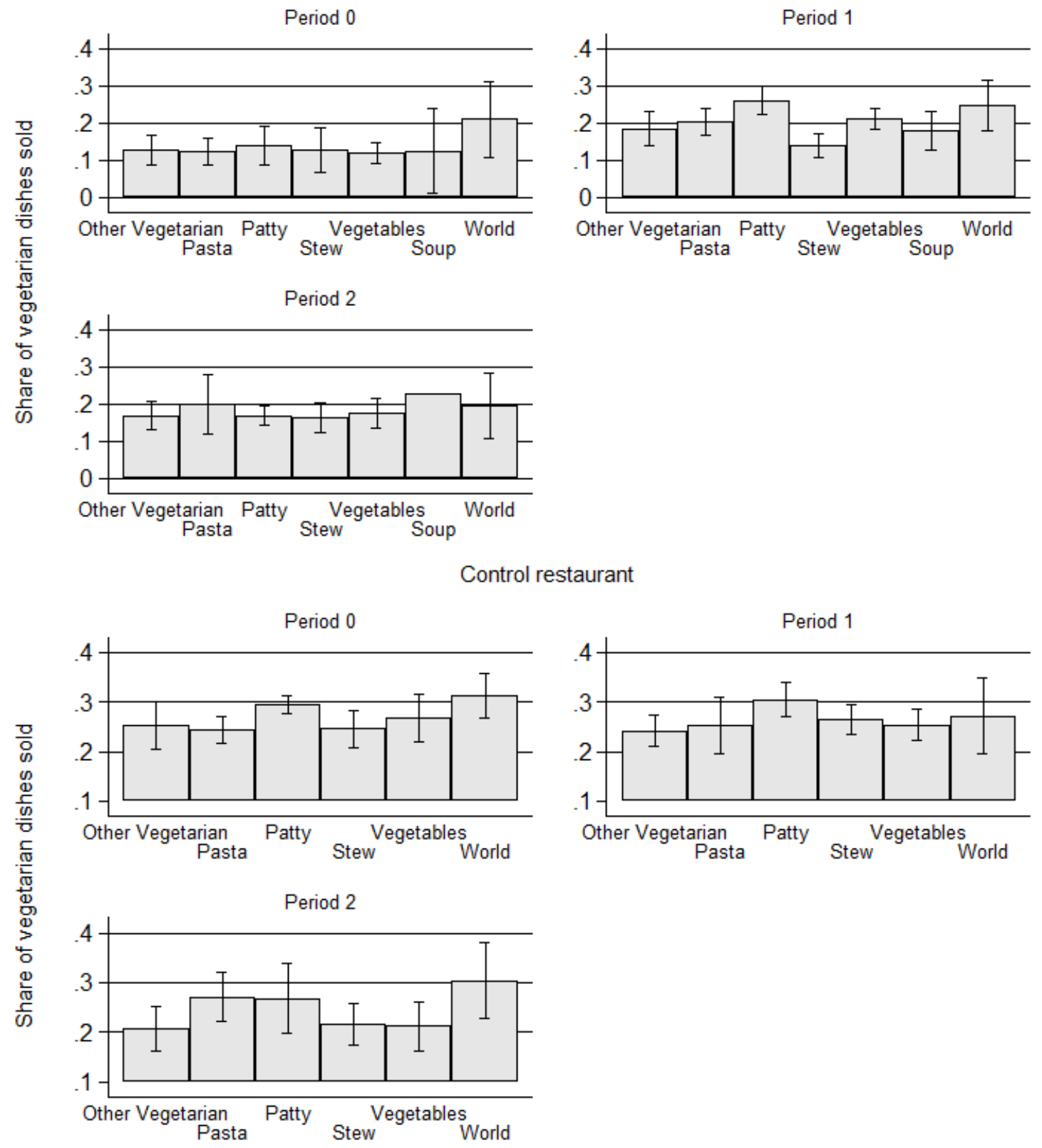

Note: Error bars represent 0.95 confidence intervals around the mean for each type. Error bar for soup in period 2 is omitted, as there was only one observation this period.

\subsection{Empirical strategy}

\subsubsection{Before-after analysis}

Building on the experimental design, two identification strategies are used to estimate the effect of the nudge and its subsequent removal on the share of vegetarian dishes sold. The first approach is to compare the sales share at the treated restaurant across periods, controlling for additional factors: 


$$
\begin{aligned}
V_{t}= & \alpha_{1}+\gamma_{1} \text { Period } 1+\gamma_{2} \text { Period } 2+\text { Vegtype } e_{t} \times \theta+\left(\text { Meattype }_{t} \times \text { Meattype }_{t}\right) \times \mu+ \\
& \lambda_{\text {day }}+\varepsilon_{t}
\end{aligned}
$$

$V_{t}$ is the share of vegetarian lunches sold at restaurant 1 on day $t$. Period 1 and Period 2 are dummy variables indicating whether an observation belongs to the treatment or the reversal period, respectively; $\gamma_{1}$ captures the effects of the combined nudge in period 1 ; and $\gamma_{2}$ captures any remaining effects of the nudge after its removal in period 2 .

Vegtype $_{t}$ is a vector of dummy variables characterizing the type of vegetarian dish served that day and is introduced to capture differences in popularity between dish types. Meattype $1_{t} \times$ Meattype $2_{t}$ is a vector of all observed combinations of meat dishes offered. ${ }^{15}$ It is introduced to control for the influence of the outside options on $V_{t}$. $\lambda_{\text {day }}$ introduces day-of-the-week fixed effects. To estimate how the nudge affects the sales of the meat 1 and meat 2 dishes, equation (1) can also be specified with the share of meat 1 or meat 2 dishes sold as the dependent variable. While the intervention directly affected the visibility and menu position of the meat 1 dish such that one would expect the sales share to decrease, sales of the meat 2 dish could be also affected. Although the menu position and visibility of this dish were kept constant throughout the experiment, the nudge might change its salience relative to the meat 1 and vegetarian dishes.

The impact of the nudge over time can be analyzed by estimating equation (1) with a linear time trend and by dividing the period dummies further into subperiods and comparing their coefficients. This can also help elucidate whether the change of chefs at the treated restaurant had an additional impact on the share of vegetarian dishes sold.

An alternative to looking separately at the share of each dish type sold as the dependent variable in a linear regression framework is to model the sales of all three dish types, vegetarian, meat 1 , and meat 2 , in a multinomial regression. This can serve as a robustness check for the ordinary least squares (OLS) results, taking into account that the share of vegetarian dishes sold results from customers facing three unordered options they can choose from, and has the advantage of simultaneously estimating the effect of the nudge on all three alternatives. I estimate the following conditional logit model with alternative-specific constants, modelling the probability $p_{t j}$ that alternative $j$ is chosen at day $t$ :

\footnotetext{
${ }^{15}$ Alternatively, one could introduce each dish type separately in the regression. However, as the consumer is always faced with a combination of dishes, and the order in which they are presented on the menu might matter for decision-making, I control for each combination of meat types occurring in the data.
} 
$p_{t j}=\operatorname{Prob}\left[Y_{t}=j\right]=\frac{\exp \left(\alpha_{j}+\text { Dishtype }_{t j} \times \rho+\gamma_{1 j} \text { Period } 1 \gamma_{2 j} \text { Period }+\lambda_{j, \text { Day }}\right)}{\sum_{k=1}^{3} \exp \left(\alpha_{k}+\text { Dishtyp }_{t k} \times \rho+\gamma_{1 k} \text { Period } 1+\gamma_{2 k} \text { Period } 2+\lambda_{k, \text { Day }}\right)}$

where $j, k=1,2$, 3 denote the three alternatives (meat 1 , meat 2, and vegetarian). Identification in the conditional logit model crucially depends on the assumption of independence of irrelevant alternatives (IIA), which excludes the presence of close substitute alternatives. As the meat 1 and meat 2 dishes are very similar, it is likely that consumers eating meat substitute between those two dishes to a greater extent than with the vegetarian dish. To relax the IIA assumption, I also estimate a partially degenerate nested logit model that partitions the choice set into one branch containing the meat alternatives and one branch containing the vegetarian alternative (see, for example, Hunt, 2000).

Estimating effects of the nudge on the share of vegetarian dishes sold by before-after analysis will give unbiased results only if factors external to the experiment that might drive changes in sales across the period can be excluded. Such external factors could, for example, be food trends, media reporting on food-related issues, or seasonal variation in consumption patterns. Given the long observation period, identification is especially sensitive to this (untestable) assumption. However, it can be relaxed by using data from restaurant 2 as a control, which should capture any exogenous changes that could affect the consumption of vegetarian food during the experiment, in a difference-in-differences analysis.

\subsubsection{Difference-in-differences analysis}

The following difference-in-differences (DiD) model is estimated to identify the effect of the nudge on the share of vegetarian dishes sold by comparing changes across periods 0 and 1 at the treated restaurant with changes at the control restaurant:

$$
\begin{aligned}
& V_{i t}=\alpha_{0}+\beta_{0} \text { Restaurant }+\gamma_{0} \text { Period } 1+\delta_{0}(\text { Restaurant } \times \text { Period } 1)+\text { Vegtype }_{i t} \times \rho+ \\
& \left(\text { Meattype }_{1 \text { it }} \times \text { Meattype }_{i t}\right) \times \tau+\lambda_{\text {Day }}+\lambda_{\text {Holidays }}+\lambda_{\text {Month }}+\varepsilon_{i t}
\end{aligned}
$$

where $V_{i t}$ is the share of vegetarian lunch dishes sold at restaurant $i$ on day $t$. Initial differences in the share of vegetarian lunches sold are captured by the dummy variable Restaurant, which is 0 for the control restaurant and 1 for the treated restaurant. Period 1 is a dummy variable taking the value 1 if an observation belongs to the treatment period and controls for changes in the popularity of vegetarian food across periods common to both restaurants. Vegtype $_{i t}$ is again a vector of dummy variables characterizing the type of vegetarian dish served, and Meattype $1_{i t} \times$ Meattype $2_{i t}$ controls for the combination of meat dishes served as outside options. $\lambda_{\text {Day }}, \lambda_{\text {Holiday }}$, and $\lambda_{\text {Month }}$ are time fixed effects controlling for the 
day of the week, for the weeks around the Christmas holidays ${ }^{16}$, and for the calendar month. Month fixed effects are especially important, as they capture any potential common effects of the chef change in February on the outcome variable. Restaurant $\times$ Period 1 indicates whether an observation belongs to the treated restaurant in the treatment period, and $\delta_{0}$ captures the treatment effect.

DiD estimation is limited to the direct effect of the nudge (i.e., the effect in period 1), as it relies on two critical assumptions to deliver unbiased treatment effects. The first assumption is that the consumption of vegetarian food followed parallel trends at both restaurants before the introduction of the nudge. The second assumption is that restaurant 2 is a valid control in the sense that any exogenous events during the experiment affected consumers at both restaurants in a similar way. This assumption is weakened by the employment of a new chef toward the end of the treatment period at the control restaurant. Figure 2, which depicts weekly average sales of vegetarian dishes by restaurant, shows that from the week the new chef started, variability increased and sales shares slightly decreased at the control restaurant. ${ }^{17}$ According to the restaurant's management, the higher variability in the share of vegetarian dishes sold was due to the fact that the new chef was not used to cooking vegetarian dishes and first had to acquire knowledge regarding the taste of his customers. Moreover, the menu order was changed for five weeks during the reversal period, such that the vegetarian dish was moved from the top to the middle of the menu. The change of chefs at restaurant 1 did not lead to a similar increase in variability, which is most likely because the new chef had worked there before as a trainee of the old chef. Hence, he already knew the taste of the customers and was familiar with cooking vegetarian dishes. Limiting the DiD analysis to period 1 safeguards against overestimating persistent effects of the nudge in period 2. In addition, equation (3) is estimated with period 1 divided further into subperiods and with a linear time trend, which can provide some information about the impact of the chef change on the treatment effect.

Figure 2 can also be used to examine the parallel trends assumption. A priori, this assumption is supported by several factors. Both restaurants are run by the same provider and subject to the same management, which minimizes the chance for management changes that affect only one restaurant. Moreover, both restaurants are located in the same city, and customers

\footnotetext{
${ }^{16}$ Potentially, more employees take holidays during these weeks, which could alter the customer composition.

${ }^{17}$ The spike in the last week of March coincides with the week before the Easter holidays, when the restaurant was open for only three days. This could have altered the composition of customers. Most likely, both the lower number of observations and the composition effect contributed to the spike in the share of vegetarian dishes sold. The treated restaurant was open for four days that week.
} 
should be exposed to roughly the same media, weather conditions, and seasonal variation in food offered. Third, although the restaurants differ with respect to the customers to whom they cater, as they belong to different faculties, the populations are similar with respect to age structure and educational attainment, increasing the likelihood that they will react to exogenous events in a similar way.

Figure 2. Share of vegetarian meals sold per week over time, both restaurants

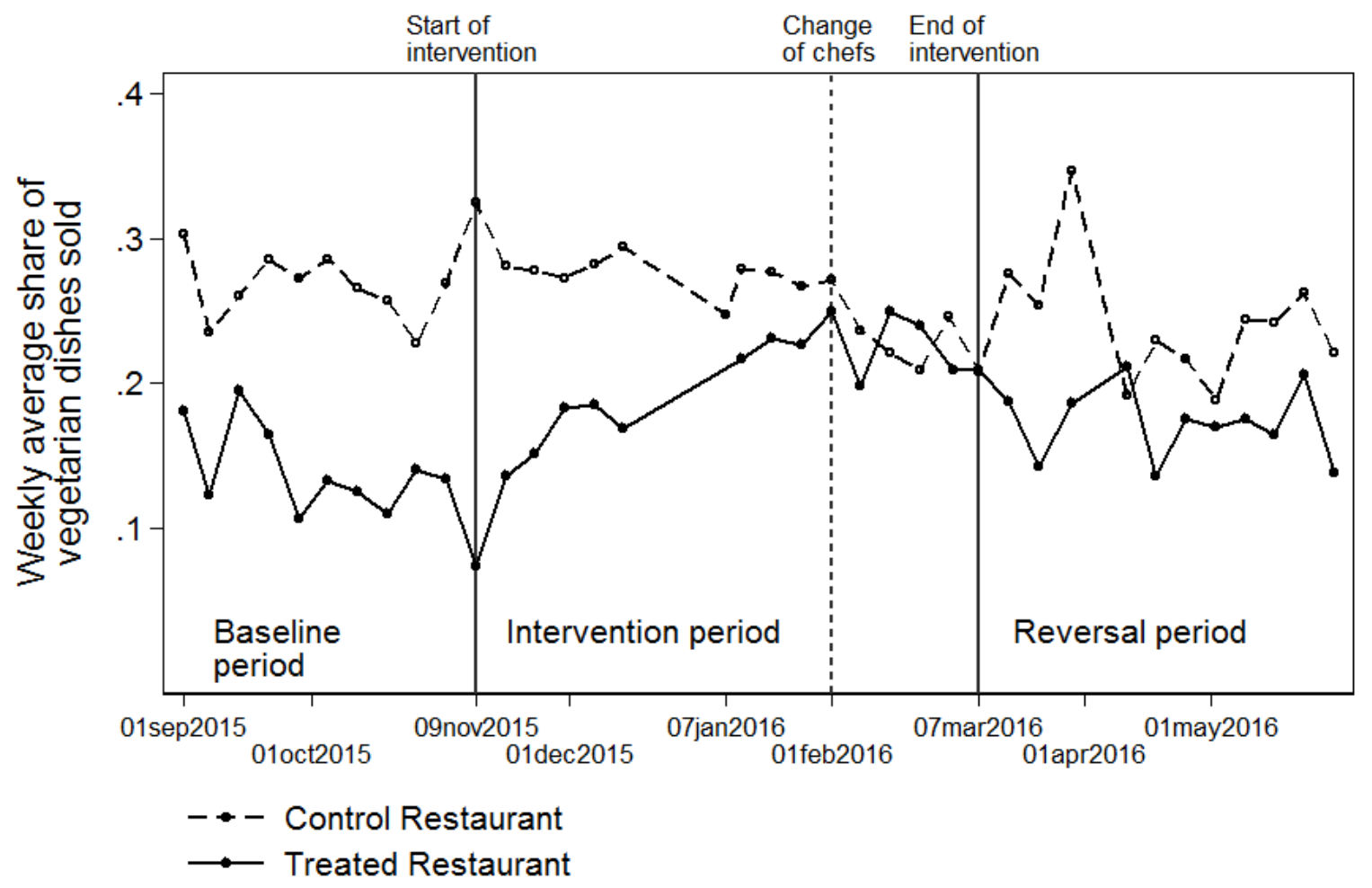

Examining pretreatment trends in Figure 2 lends support to the assumption of parallel trends during the baseline period. At the control restaurant, the share of vegetarian dishes sold did not trend upward or downward until the new chef was employed. The apparent spike at the start of the intervention was most likely caused by the type of vegetarian dishes offered, which was a dish belonging to the most popular category (patties) during three out of five days. At the treated restaurant, the share of vegetarian dishes sold exhibits more variation but no clear trend during the preintervention period, and it increased steadily after the implementation of the nudge. The drop exactly at the start of the intervention was most likely caused by the fact that a job fair was taking place at the treated restaurant; only one day of sales data was delivered during that week. On that day, a vegetarian dish belonging to one of the least popular categories, stew, was sold. During the reversal period, the share of vegetarian lunches at the treated restaurant dropped compared with the intervention period but was still slightly higher than during the baseline period. 
In addition to using a linear DiD model, sales in period 1 are also modelled by a conditional logit model and a nested model to relax the IIA assumption. The conditional logit model takes the following form, where $p_{i t j}$ denotes the probability that alternative $j$ is chosen in restaurant $i$ at day $t$, and $R$ and $P 1$ are dummies for restaurant 1 and period 1 , respectively:

$p_{t j}=\operatorname{Prob}\left[Y_{t i}=j\right]=\frac{\exp \left(\alpha_{j}+\beta_{j} R+\gamma_{j} P 1+\delta_{j}(R \times P 1)+\text { Dishtype }_{i t j} \times \rho+\lambda_{j, \text { Day }}+\lambda_{j, \text { Holid }}+\lambda_{j, \text { Month }}\right)}{\sum_{k=1}^{3} \exp \left(\alpha_{k}+\beta_{k} R+\gamma_{k} P 1+\delta_{k}(R \times P 1)+\text { Dishtype }_{i t k} \times \rho+\lambda_{k, \text { Day }}+\lambda_{k, \text { Holid }}+\lambda_{k, \text { Month }}\right)}$

\section{Results}

\subsection{Preliminary analysis}

Table 2 compares the average shares of vegetarian dishes sold across periods and restaurants. At the treated restaurant, the share significantly increased by 6 percentage points, from 14 to 20 percent, after implementing the nudge, while it remained stable at around 26 percent at the control restaurant. Comparing the changes in the share of vegetarian dishes sold at the treated restaurant between period 0 and period 1 to changes in sales share at the control restaurant across the same periods provides the unconditional $\mathrm{DiD}$ treatment effect. Without controlling for additional factors, the share of vegetarian dishes sold at the treated restaurant increased by 6 percentage points (column (4)). In period 2, the share of vegetarian lunches sold dropped to around 18 percent and 24 percent at the treated and control restaurants, respectively. Comparing the shares in period 0 and period 2 at the treated restaurant shows that the sales share of vegetarian lunches was still 3.6 percentage points higher after the nudge was removed than during the baseline period. The DiD estimate is significantly higher but most likely confounded by the drop in sales shares in connection with the employment of the new chef at the control restaurant.

Table 3. Mean shares of vegetarian dishes sold across periods and restaurants

\begin{tabular}{lcccccc}
\hline \hline Share of vegetarian dishes sold & $\begin{array}{c}(1) \\
\text { Period 0 }\end{array}$ & $\begin{array}{c}(2) \\
\text { Period 1 }\end{array}$ & $\begin{array}{c}(3) \\
\text { Period 2 }\end{array}$ & $\begin{array}{c}(4) \\
\text { Period 1- } \\
\text { Period 0 }\end{array}$ & $\begin{array}{c}(5) \\
\text { Period 2- } \\
\text { Period 0 }\end{array}$ & $\begin{array}{c}(6) \\
\text { Period 2- } \\
\text { Period 1 }^{a}\end{array}$ \\
\hline Treated restaurant & 0.139 & 0.201 & 0.176 & $0.062^{* * *}$ & $0.036^{* * *}$ & $-0.025^{* * *}$ \\
& $(0.0038)$ & $(0.0040)$ & $(0.0046)$ & $(0.0055)$ & $(0.0059)$ & $(.0060)$ \\
Control restaurant & 0.264 & 0.267 & 0.240 & -0.003 & $-0.025^{* * *}$ & $-0.026^{* * *}$ \\
& $(0.0051)$ & $(0.0044)$ & $(0.0051)$ & $(0.0067)$ & $(.0072)$ & $(0.0067)$ \\
Difference-in-differences & & & & $0.060^{* * *}$ & $0.061^{* * *}$ & 0.001 \\
treated - control ${ }^{b}$ & & & & $(0.0166)$ & $(0.0180)$ & $(0.0170)$ \\
\hline \hline${ }^{a}$ z-test of proportions & & & & &
\end{tabular}




\subsection{Regression analysis: Immediate effects of the nudge}

Table 4 presents the estimated effects of the nudge in period 1, using the before-after approach in columns (1) - (4) and the DiD approach in columns (5) - (8). Column 1 shows the raw before-after comparison; the share of vegetarian dishes sold significantly increases by 6.2 percentage points. Columns (2) and (3) add controls for the types of vegetarian and meat dishes sold each day. Although appendix Table A.1 shows that the menu composition varied across periods, controlling for it only marginally changes the treatment effect- to 6.4 percentage points when including the type of vegetarian dish and to 7.2 percentage points when including the types of meat dishes. Including weekday fixed effects (column (4)) increases the treatment effect further to 8.2 percentage points. Testing for pairwise differences reveals that treatment effects are not significantly different across specifications. Columns (5) - (8) show the results of the DiD estimation. DiD estimates of the treatment effect lie between 6 and 7.3 percentage points and are thus very close to the before-after estimates. Pairwise comparisons show no difference in the treatment effects across models. A minimum treatment effect of 6 percentage points, as found in the specification in column (5), represents a 43 percent increase in the share of vegetarian lunches sold, compared with the baseline period, as the result of the nudge. 


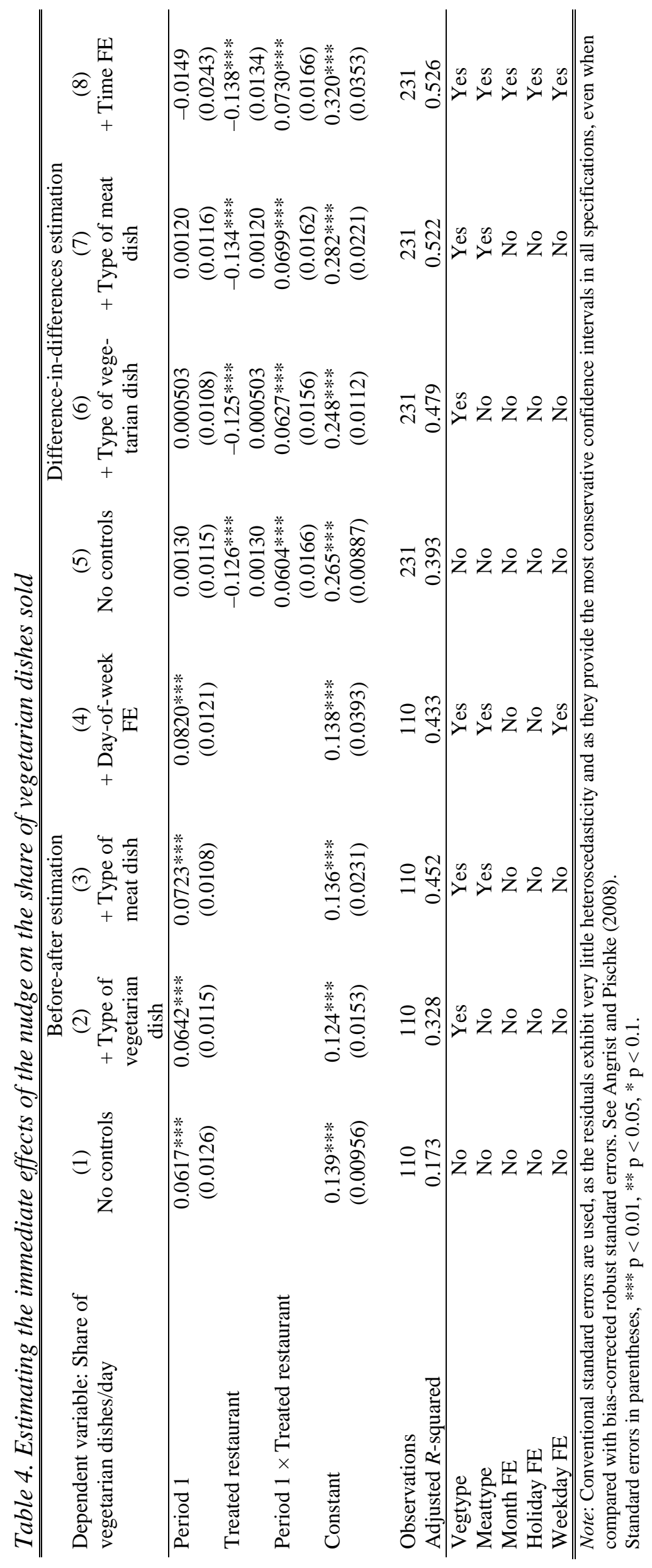


To analyze the development of the treatment effect over time, the intervention period is split into three subperiods: November-December, January, and February-March. ${ }^{18}$ Results in columns (1) and (4) of Table 5 confirm the graphical analysis: the size of the treatment effect increases over time, from 4.1 to 11.3 percentage points when estimated by a before-after comparison, and from (insignificant) 1.2 to 13.5 percentage points when estimated by DiD. ${ }^{19}$ The effect for February-March is most likely slightly overestimated in the DiD specification, as these are the months when the new chef was employed and the share of vegetarian dishes dropped slightly at the control restaurant (see Figure 2). However, the effect for FebruaryMarch does not differ significantly between the before-after and the DiD specification. ${ }^{20}$

Estimating the treatment effect with a linear time trend (columns (2), (3), and (5)) shows that the nudge led to an increase of 0.8-0.9 percentage points in the share of vegetarian dishes sold each week. In column (2), a weekly linear trend is estimated using only data from the treated restaurant up to February 1, when the new chef started. Column (3) estimates the trend using all of period 1 but includes a dummy for the period February-March. The trend slightly decreases but is not significantly different from using only the data up to the chef change $(\mathrm{p}=$ 0.10 ), providing evidence that the change of chefs at the treated restaurant did not significantly change the impact of the nudge. Excluding the first week of the intervention, which represents a potential outlier at both restaurants (see Figure 2), as a robustness check for the linear time trend decreases the weekly trend to $0.75-0.84$ percentage points, depending on the specification used. $^{21}$

As individual-level data is not available, it is impossible to identify the mechanism behind the increasing treatment effect. One potential explanation is that an increasing number of individuals were exposed to the nudge over the course of the intervention. A guest survey conducted in May 2015 revealed that on average, customers eat at the restaurant about four times per month. If initially nudged customers subsequently increased their consumption of vegetarian food further, such as predicted by the models of Becker and Murphy (1988) or Naik and Moore (1996), this could result in an increasing treatment effect over time. Another explana-

\footnotetext{
${ }^{18}$ November and December were grouped because only about half of November was treated and the Christmas break started December 19. February and March were grouped because only one week in March was treated.

${ }^{19}$ In model (1), pairwise comparison of treatment effects shows that the effects for January and February-March are not significantly different from each other. Both other pairwise comparisons show significant differences. In model (4), all pairwise comparisons show that monthly, the treatment effect increases over time.

${ }^{20}$ Treatment effects for November-December are significantly different at a 5\% level in both the before-after and the DiD specifications. Effects for January and February-March are not significantly different ( $\mathrm{p}=0.08$ and $\mathrm{p}=0.13$, respectively).

${ }^{21}$ Full results of the regressions excluding the first week of the intervention are available on request.
} 
tion could be that any increase in the sales of vegetarian dishes as a result of the nudge increased sales further via network effects, such as if people recommended the dish to colleagues or if customers observed what others chose. Such effects could lead to increasing sales over time, even if the additional sales might not be directly attributable to the nudge.

Table 5. Treatment effects over time

\begin{tabular}{|c|c|c|c|c|c|}
\hline & \multicolumn{3}{|c|}{ 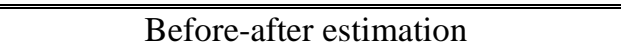 } & \multicolumn{2}{|c|}{ DiD estimation } \\
\hline & $\begin{array}{c}\text { (1) } \\
\text { Monthly } \\
\text { treatment } \\
\text { effects }\end{array}$ & $\begin{array}{c}\text { (2) } \\
\text { Linear time } \\
\text { trend, be- } \\
\text { fore chef } \\
\text { change }\end{array}$ & $\begin{array}{c}(3) \\
\text { Linear time } \\
\text { trend, whole } \\
\text { period }\end{array}$ & $\begin{array}{c}(4) \\
\text { Monthly } \\
\text { treatment } \\
\text { effects }\end{array}$ & $\begin{array}{l}\text { (5) } \\
\text { Linear time } \\
\text { trend }\end{array}$ \\
\hline Period 1 & & & & & $\begin{array}{l}0.00788 \\
(0.0215)\end{array}$ \\
\hline Restaurant 1 & & & & $\begin{array}{c}-0.142 * * * \\
(0.0125)\end{array}$ & $\begin{array}{c}-0.146 * * * \\
(0.0111)\end{array}$ \\
\hline Period $1 \times$ Restaurant 1 & & & & & \\
\hline Nov-Dec $\times$ Restaurant 1 & $\begin{array}{c}0.0407 * * * \\
(0.0142)\end{array}$ & & & $\begin{array}{c}0.0115 \\
(0.0197)\end{array}$ & \\
\hline Jan $\times$ Restaurant 1 & $\begin{array}{c}0.0968 * * * \\
(0.0159)\end{array}$ & & & $\begin{array}{c}0.0733^{* * *} \\
(0.0228)\end{array}$ & \\
\hline Feb-Mar $\times$ Restaurant 1 & $\begin{array}{c}0.113^{* * *} \\
(0.0146)\end{array}$ & & & $\begin{array}{l}0.135 * * * \\
(0.0199)\end{array}$ & \\
\hline $\begin{array}{l}\text { Weekly trend } \times \text { Period } 1 \times \\
\text { Restaurant } 1\end{array}$ & & $\begin{array}{l}0.0090 * * * \\
(0.0014)\end{array}$ & $\begin{array}{c}0.0083 * * * \\
(0.0014)\end{array}$ & & $\begin{array}{c}0.0085^{* * *} \\
(0.0012)\end{array}$ \\
\hline Constant & $\begin{array}{c}0.152 * * * \\
(0.0353)\end{array}$ & $\begin{array}{l}0.158 * * * \\
(0.0347)\end{array}$ & $\begin{array}{l}0.162 * * * \\
(0.0350)\end{array}$ & $\begin{array}{c}0.319 * * * \\
(0.0337)\end{array}$ & $\begin{array}{c}0.304 * * * \\
(0.0328)\end{array}$ \\
\hline Observations & 110 & 87 & 110 & 231 & 231 \\
\hline Adjusted $R$-squared & 0.547 & 0.521 & 0.539 & 0.591 & 0.587 \\
\hline Vegtype & Yes & Yes & Yes & Yes & Yes \\
\hline Meattype & Yes & Yes & Yes & Yes & Yes \\
\hline New chef & No & No & Yes & No & No \\
\hline Month FE & No & No & No & Yes & Yes \\
\hline Holiday FE & No & No & No & Yes & Yes \\
\hline Weekday FE & Yes & Yes & Yes & Yes & Yes \\
\hline
\end{tabular}

Note: The baseline specifications shown in columns (1) and (4) correspond with columns (4) and (8) in Table 4.

Standard errors in parentheses, *** $\mathrm{p}<0.01$, ** $\mathrm{p}<0.05,{ }^{*} \mathrm{p}<0.1$.

\subsection{Persistent effects of the nudge on the share of vegetarian dishes sold}

Table 6 shows the results of the before-after regressions testing for persistent changes in the share of vegetarian dishes sold after removing the nudge. When estimating the full model, including controls for dish types and weekday fixed effects (column (4)), the share of vegetarian lunches is still around 4 percentage points higher than in the baseline period. Combining the results from the analysis of treatment effect over time and from the reversal of the inter- 
vention, the nudge seems to have led to a persistent shift in consumption toward more vegetarian food. ${ }^{22}$

Table 6. Estimating persistent effects of the nudge on the share of vegetarian dishes sold

\begin{tabular}{lcccc}
\hline $\begin{array}{l}\text { Dependent variable: Share of } \\
\text { vegetarian dishes sold per day }\end{array}$ & $\begin{array}{c}(1) \\
\text { No controls }\end{array}$ & $\begin{array}{c}(2) \\
\text { + Type of vege- } \\
\text { tarian dish }\end{array}$ & $\begin{array}{c}(3) \\
+ \text { Type of meat } \\
\text { dish }\end{array}$ & $\begin{array}{c}\text { (4) } \\
\text { + Day-of-week } \\
\text { FE }\end{array}$ \\
\hline Period 1 & $0.0617^{* * *}$ & $0.0642^{* * *}$ & $0.0703^{* * *}$ & $0.0703^{* * *}$ \\
& $(0.0122)$ & $(0.0117)$ & $(0.0118)$ & $(0.0122)$ \\
Period 2 & $0.0365^{* * *}$ & $0.0367^{* * *}$ & $0.0404^{* * *}$ & $0.0409^{* * *}$ \\
& $(0.0125)$ & $(0.0121)$ & $(0.0124)$ & $(0.0126)$ \\
Constant & $0.139 * * *$ & $0.127^{* * *}$ & $0.148^{* * *}$ & $0.154^{* * *}$ \\
& $(0.00922)$ & $(0.0136)$ & $(0.0279)$ & $(0.0315)$ \\
Observations & & & & 166 \\
Adjusted $R$-squared & 166 & 166 & 166 & 0.268 \\
\hline Vegtype & 0.125 & 0.209 & 0.286 & Yes \\
Meattype & No & Yes & Yes & Yes \\
Month FE & No & No & Nes & No \\
Holiday FE & No & No & No & No \\
Weekday FE & No & No & No & Yes \\
\hline \hline
\end{tabular}

Note: Conventional standard errors are used as the residuals exhibit very little heteroscedasticity and as they provide the most conservative confidence intervals in all specifications, even when compared with bias-corrected robust standard errors.

Standard errors in parentheses ${ }^{* * *} \mathrm{p}<0.01,{ }^{* *} \mathrm{p}<0.05, * \mathrm{p}<0.1$.

\subsection{Heterogeneous effects: Type of vegetarian dish served}

As Figure 1 shows, the sales share of vegetarian dishes varied considerably with the type of dish offered. This section analyzes whether the impact of the nudge varied across dish types. Changing the visibility of the dish can be expected to have a differential impact, depending on how appealing a dish looks and how this contrasts with the expectations formed by the customers when only reading the name of a dish.

Figure 3 shows how the sales share of vegetarian dishes changed across periods for each type of dish at the treated restaurant, according to the classification used in the regression analysis. It can be seen that the intervention increased the sales of all vegetarian dish types, but effects vary considerably across types. The nudge seems to work most effectively when a vegetarian patty is sold and least effectively when a stew is sold. One explanation could be that the appearance of patties, such as vegetarian burgers, appeals more to customers who usually consume meat or fish, as they resemble typical meat dishes. This explanation is corroborated by previous research finding that industry meat substitutes, such as soy burgers, are

\footnotetext{
${ }^{22}$ There is no evidence for a decline in the share of vegetarian dishes sold during the reversal period. When the reversal period is divided into two parts (March-April and May-June), treatment effects are 0.044 and 0.036, respectively, and not significantly different from each other. Results for the split reversal period are available on request.
} 
relatively popular meat substitutes for consumers adhering to flexible diets (i.e., those that are neither vegetarians nor heavy meat eaters) (Schösler et al., 2012). Stews, on the other hand, seem to attract only the core vegetarian customers even during the treatment condition, as their share hardly increased while the nudge was implemented. However, although the effects for patties and vegetables are large in absolute terms in period 1, none are statistically significant when tested in a regression (see appendix Table A.2), which could be due to the relatively low frequency with which each category was served.

Figure 3. Share of vegetarian dishes sold across periods, by type of vegetarian dish

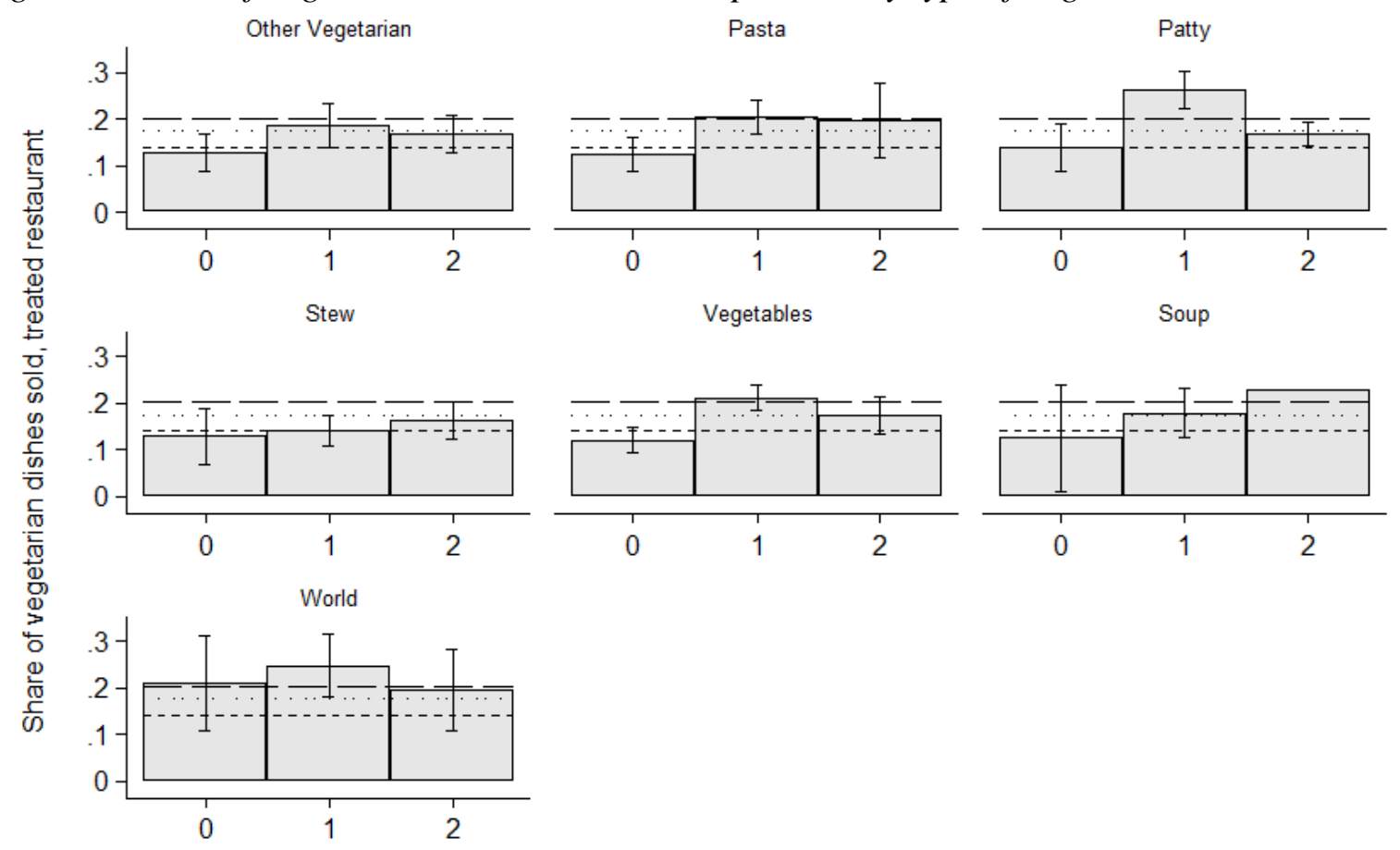

Period

Note: The short dashed lines represent the mean share of vegetarian dishes sold in period 0; long dashed lines, the mean share sold in period 1; and dotted lines, mean shares sold in period 2. Error bars represent 0.95 confidence intervals around the mean for each type.

\subsection{Alternative model specifications and substitution effects}

Although the nudge changed only how the vegetarian and meat 1 dishes were presented, Figure 4 provides some indication that the sales share of the meat 2 dish was also affected by the intervention. Plotting the sales shares of all three dish types shows that the meat 1 and meat 2 dish were close substitutes, as their sales are highly negatively correlated $(r=-0.84)$. It also shows an increase in the unconditional sales share of the meat 2 dish (not controlling for dish types or time effects) during period 1 and period 2 compared with the baseline period. 


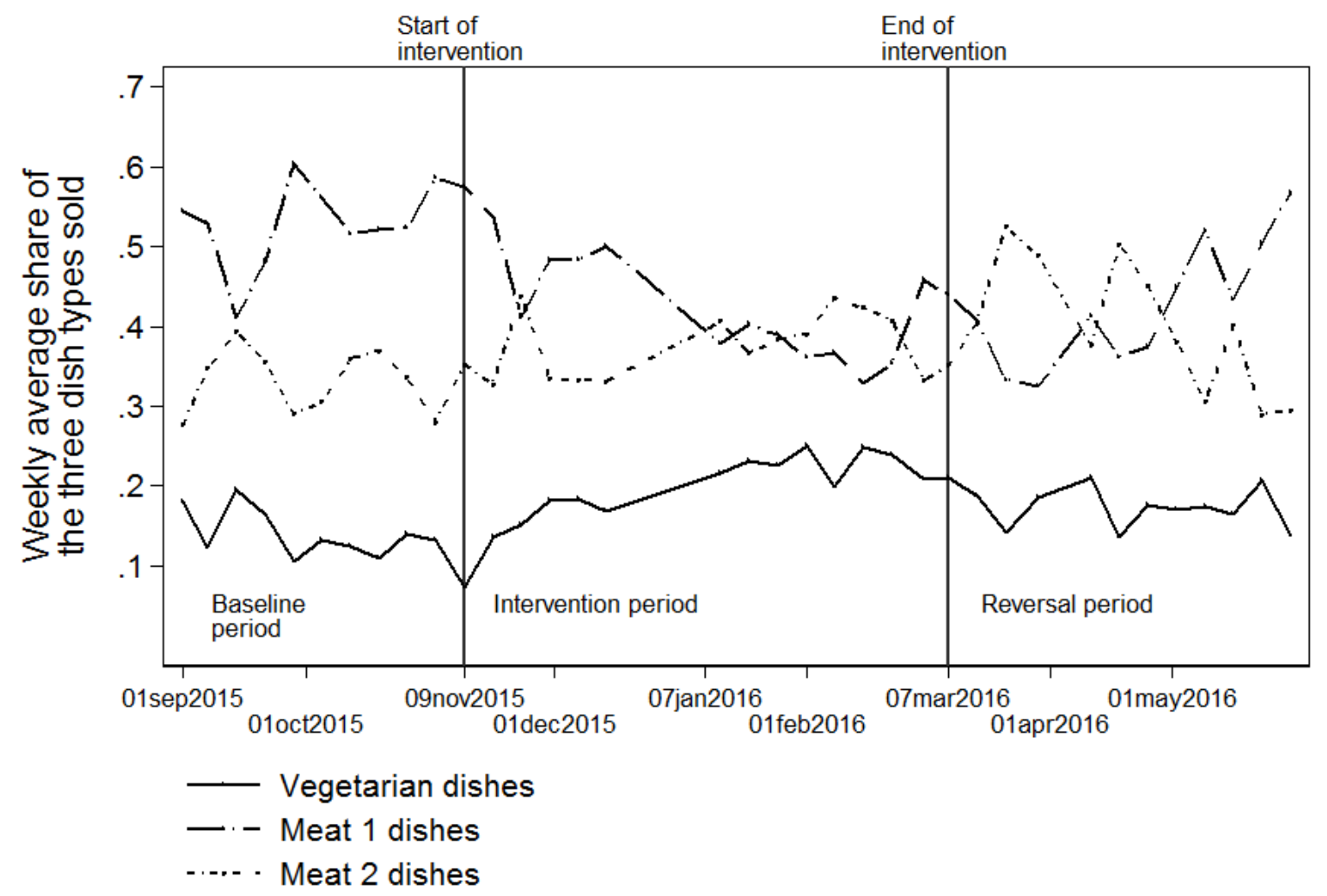

Regression results confirm the graphical analysis. Table 7 shows treatment effects on all three dish types resulting from estimating OLS, conditional logit and nested logit regressions, controlling for the type of meat or vegetarian food served and time. The coefficients shown are the marginal effects of the treatment on the sales shares. ${ }^{23}$ Estimated treatment effects are largely similar, showing that the OLS results are robust to alternative model specifications.

Results from the nested logit models, which are preferred over the conditional logit results because they are not sensitive to the IIA assumption,24 show that the increase in the number of vegetarian dishes sold was accompanied by a decrease in the meat 1 dish by around 10 percentage points and an increase in the meat 2 dish by around 4 percentage points in period 1 if estimated using the before-after specification, and all effects persist into period 2 when the

\footnotetext{
${ }^{23}$ Puhani (2012) shows that the treatment effect in nonlinear difference-in-differences models is given by the incremental effect of the treatment indicator on the outcome variable: $\frac{\Delta P r\left[y_{i t}=j\right]}{\Delta \text { Period } 1 \times \text { Rest } 1}=$

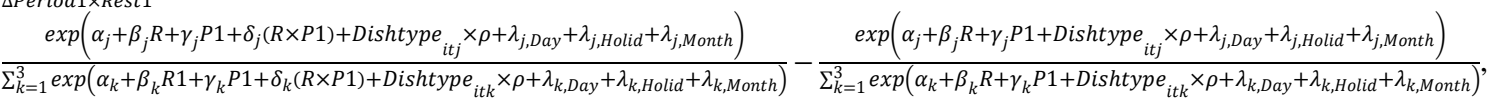

where $j, k=1,2,3$ denote the three dish alternatives. The treatment effect is estimated as the marginal effect at data means. Standard errors are obtained by using the delta method.

${ }^{24}$ A formal Hausman test of the IIA assumption did not provide valid results, as the covariance matrix for the difference between the restricted and unrestricted models was not positive definite. This is most likely a finite sample problem. As the IIA cannot be assumed to hold, and the nested logit model should be preferred.
} 
nudge was removed. When estimating via the difference-in-difference approach, the negative effect on the meat 1 dish drops to around six percentage points, while the effect on the meat 2 dish disappears. As shown in Table 2, sales of the meat 1 dish decrease in favor of the meat 2 dish at the control restaurant in period 1 , causing the change in the regression coefficients on the meat 1 and meat 2 dish at the treated restaurant.

Table 7. Treatment effects on all three dishes sold

\begin{tabular}{|c|c|c|c|c|c|c|}
\hline \multirow[b]{2}{*}{ Treatment effects } & \multicolumn{3}{|c|}{ Before-after } & \multicolumn{3}{|c|}{ Difference-in-differences } \\
\hline & $\mathrm{OLS}^{a}$ & $\begin{array}{c}\text { Conditional } \\
\text { logit }^{b} \\
\end{array}$ & Nested $\log i t^{c}$ & $\mathrm{OLS}^{d}$ & $\begin{array}{c}\text { Conditional } \\
\text { logit }^{e}\end{array}$ & Nested logit ${ }^{f}$ \\
\hline \multicolumn{7}{|c|}{ Outcome: Share of vegetarian dishes sold } \\
\hline Period 1 & $\begin{array}{c}0.0703^{* * *} \\
(0.0122)\end{array}$ & $\begin{array}{c}0.0595 * * * \\
(0.0057)\end{array}$ & $\begin{array}{c}0.0616^{* * *} \\
(0.0058)\end{array}$ & $\begin{array}{c}0.0730 * * * \\
(0.0166)\end{array}$ & $\begin{array}{c}0.0598 * * * \\
(0.0072)\end{array}$ & $\begin{array}{c}0.0616 * * * \\
(0.0071)\end{array}$ \\
\hline Period 2 & $\begin{array}{c}0.0409 * * * \\
(0.0126)\end{array}$ & $\begin{array}{c}0.0339 * * * \\
(0.006)\end{array}$ & $\begin{array}{c}0.0348 * * * \\
(0.006)\end{array}$ & & & \\
\hline \multicolumn{7}{|c|}{ Outcome: Share of meat 1 dishes sold } \\
\hline Period 1 & $\begin{array}{c}-0.0889 * * * \\
(0.0247)\end{array}$ & $\begin{array}{c}-0.1050 * * * \\
(0.0077)\end{array}$ & $\begin{array}{c}-0.1053 * * * \\
(0.0081)\end{array}$ & $\begin{array}{c}-0.0528 * \\
(0.0282)\end{array}$ & $\begin{array}{c}-0.0654 * * * \\
(0.0113)\end{array}$ & $\begin{array}{c}-0.0629 * * * \\
(0.0114)\end{array}$ \\
\hline Period 2 & $\begin{array}{c}-0.0861 * * * \\
(0.0269)\end{array}$ & $\begin{array}{c}-0.1015^{* * *} \\
(0.0083)\end{array}$ & $\begin{array}{c}-0.0893 * * * \\
(0.0087)\end{array}$ & & & \\
\hline \multicolumn{7}{|c|}{ Outcome: Share of meat 2 dishes sold } \\
\hline Period 1 & $\begin{array}{c}0.0227 \\
(0.0246)\end{array}$ & $\begin{array}{c}0.0455 * * * \\
(0.0073)\end{array}$ & $\begin{array}{c}0.0436 * * * \\
(0.0079)\end{array}$ & $\begin{array}{c}-0.00447 \\
(0.029)\end{array}$ & $\begin{array}{l}0.0057 \\
(0.011)\end{array}$ & $\begin{array}{c}0.0013 \\
(0.0111)\end{array}$ \\
\hline Period 2 & $\begin{array}{l}0.0640 * * \\
(0.0257)\end{array}$ & $\begin{array}{c}0.0676 * * * \\
(0.008)\end{array}$ & $\begin{array}{c}0.0545 * * * \\
(0.0085)\end{array}$ & & & \\
\hline $\begin{array}{l}\text { No. of observat- } \\
\text { ions }\end{array}$ & 166 & 166 & 166 & 231 & 231 & 231 \\
\hline Vegtype & Yes & Yes & Yes & Yes & Yes & Yes \\
\hline Meattype & Yes & Yes & Yes & Yes & Yes & Yes \\
\hline Month FE & No & No & No & Yes & Yes & Yes \\
\hline Holiday FE & No & No & No & Yes & Yes & No \\
\hline Weekday FE & Yes & Yes & Yes & Yes & Yes & Yes \\
\hline
\end{tabular}

${ }^{a}$ As specified in equation (1). Results are obtained from three separate OLS regressions with either the share of vegetarian dishes, meat 1 , or meat 2 dishes sold as the dependent variable.

${ }^{b}$ As specified in equation (2).

${ }^{c}$ Nested multinomial logit model with the two meat alternatives specified as belonging to the same branch and the vegetarian alternative as a second branch.

${ }^{d}$ As specified in equation (3). Results are obtained from three separate OLS regressions with either the share of vegetarian dishes, meat 1 , or meat 2 dishes sold as the dependent variable.

${ }^{e}$ As specified in equation (4).

${ }^{f}$ Nested multinomial logit model with the two meat alternatives belonging to the same branch and the vegetarian alternative as a second branch. The holiday fixed effect for the Christmas holidays is omitted because it kept the model from converging.

\subsection{Changes in the menu order at the control restaurant}

The experimental setup at the treated restaurant does not allow disentangling which part of the nudge caused the increase in the share of vegetarian lunches sold: the change in the menu 
order or the increased visibility of the vegetarian dish. ${ }^{25}$ Evidence that changing the menu order in isolation play at least some role comes from the control restaurant. As mentioned earlier, the new chef changed the menu order during five nonconsecutive weeks, resulting in 22 days with a changed order out of the 79 days in the sample when the new chef was employed. Despite the small sample, when regressing daily sales of all three dish types on a dummy for changed menu order, type of meat or vegetarian dish, and weekday fixed effects in a nested logit model, there is a significant negative effect of -2.4 percentage points from listing the vegetarian dish in the middle instead of at the top (see Table 8). The effect of being put at the top is larger; sales of the meat 1 dish increased by around 4 percentage points on the days when the menu order was changed. The reduction in sales of the meat 2 dish is not significant but still indicates that there was some substitution from the meat 2 to the meat 1 dish when the latter was placed at the top. ${ }^{26}$ Analyzing the menu changes in the control restaurant shows that it is possible not only to be nudged into switching to vegetarian food, but also to be nudged away from it.

Table 8. Effects of the change in the menu order at the control restaurant

\begin{tabular}{lccc}
\hline \hline & & Nested logit model & \\
& $\begin{array}{c}\text { Share of vegetarian } \\
\text { dishes sold }\end{array}$ & $\begin{array}{c}\text { Share of meat } 1 \\
\text { dishes sold }\end{array}$ & $\begin{array}{c}\text { Share of meat } 2 \\
\text { dishes sold }\end{array}$ \\
\hline Menu order changed & $-0.0237^{* *}$ & $0.0380^{* * *}$ & -0.0143 \\
& $(0.0097)$ & $(0.0123)$ & $(0.0119)$ \\
Observations & 79 & 79 & 79 \\
\hline Vegtype & Yes & Yes & Yes \\
Meattype & Yes & Yes & Yes \\
Weekday FE & Yes & Yes & Yes \\
\hline \hline
\end{tabular}

Note: Only observations when the new chef was employed were used ( 17 weeks of data), of which the menu order was changed during five weeks. Treatment effects are calculated as the incremental effect of the treatment indicator on the outcome variable (Puhani, 2012) and as marginal effects at data means. Standard errors are obtained by using the delta method. Standard errors in parentheses, $* * * \mathrm{p}<0.01,{ }^{* *} \mathrm{p}<0.05,{ }^{*} \mathrm{p}<0.1$.

\footnotetext{
${ }^{25}$ A priori, it seems more likely that it was the increased visibility that, via a change in saliency and additional information, caused most of the treatment effect. Order effects based on growing fatigue or satisficing behavior seem more apt to arise with longer lists, and previous studies included lists containing many more items than the menus in this study (for example, Dayan and Bar-Hillel, 2011; Feenberg et al., 2015; Policastro et al., 2015). Confirmatory bias, on the other hand, might cause a primacy effect even with such a short list.

${ }^{26}$ The results of changing the menu order at the control restaurant are robust to excluding the outlier identified in Figure 2. Excluding that week changes the effect on the vegetarian dish to -0.0216 but leaves significance unaffected. The effect on meat 1 slightly increases to 0.04062, while the effect on meat 2 remains insignificant.
} 


\section{Effects of the treatment on lunch GHG emissions}

\subsection{Substituted dishes}

To evaulate the potential of nudging for decreasing food-related GHG emissions, it is necessary to study which type of meat customers substitute away from when being nudged into choosing a vegetarian meal, as different types of meat imply different emissions intensities per $\mathrm{kg}$ consumed. In terms of average $\mathrm{CO}_{2}$ equivalents $\left(\mathrm{CO}_{2} \mathrm{e}\right)$ emitted per $\mathrm{kg}$ of meat sold in Sweden, $1 \mathrm{~kg}$ of beef causes the highest emissions, followed by lamb, mixed meats (such as minced meat), pork, chicken, and fish (Bryngelsson et al., 2016). Thus, if consumers substitute vegetarian meals for fish and chicken as a result of the nudge, emissions reductions will be lower than if they reduce their consumption of red meat.

Figure 5. Shares of meat 1 dishes sold by type of meat across periods, treated restaurant

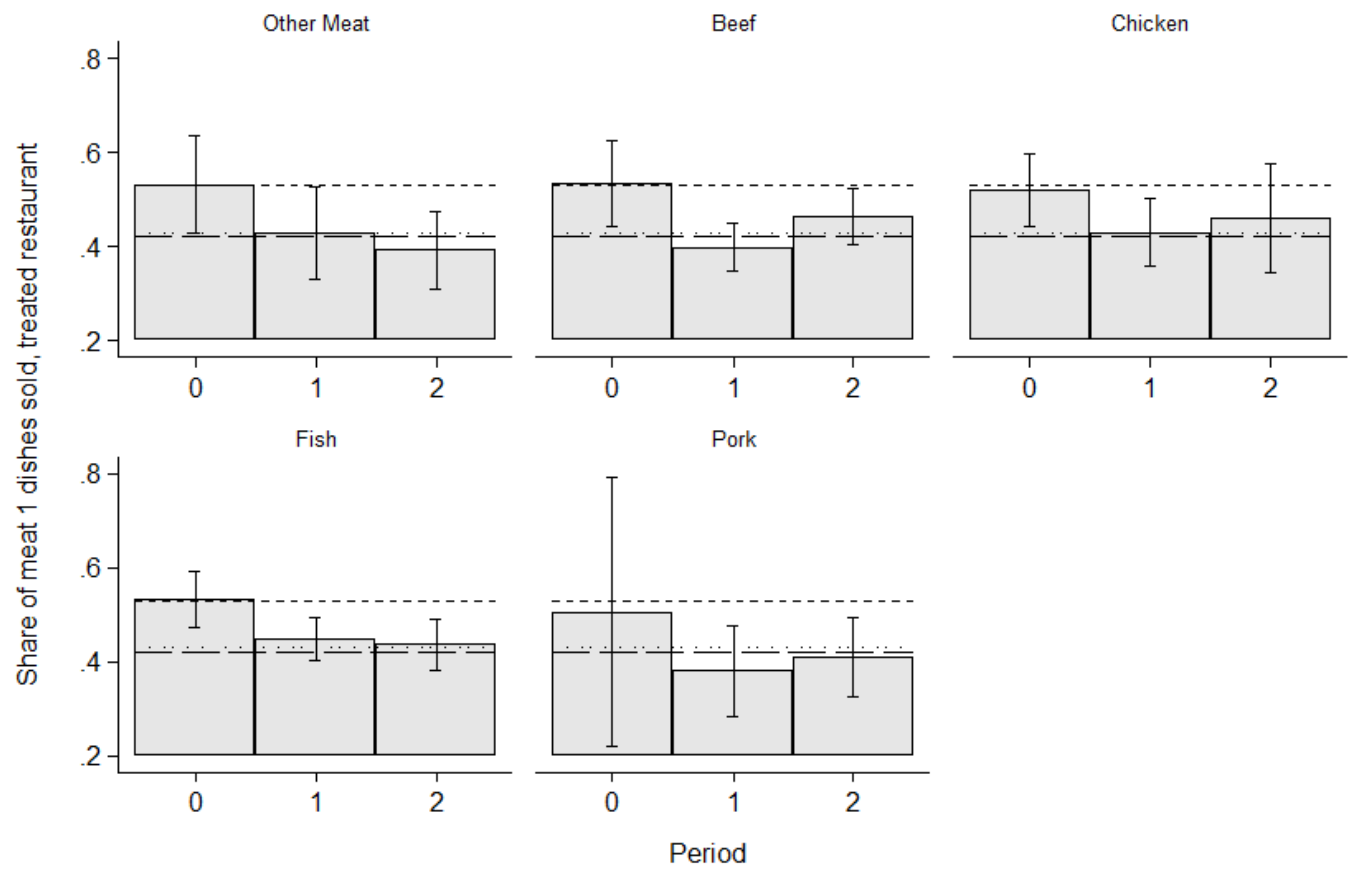

Note: The short dashed lines represent the mean share of meat 1 dishes sold in period 0 ; long dashed lines, the mean share sold in period 1; and dotted lines, mean shares sold in period 2. Error bars represent 0.95 confidence intervals around the mean for each type.

Figure 5 shows that the reduction in sales shares is close to the average reduction for all types of meat served as the meat 1 dish. ${ }^{27}$ Figure A.2 in the appendix shows a similar result for meat 2 dishes: the increase in sales of vegetarian dishes did not depend on the type of meat

\footnotetext{
${ }^{27}$ Soup was never served as a meat 1 dish in period 0 and was served only twice in period 1 , so it was added to the pork dishes, as its regular version contains bacon.
} 
served ${ }^{28}$ For the calculation of climate impacts, it is thus assumed that the nudge affects dishes of the same type (meat 1 , meat 2 , vegetarian) uniformly.

\subsection{Approximating the reduction in GHG emissions}

How big is the impact of the intervention on GHG emissions of the restaurant? With the help of a few assumptions, a back-of-the-envelope calculation of the impact of the nudge on GHG emissions can be performed. The chef of the treated restaurant provided information on the standard quantities of meat, vegetables, carbohydrates, vegetarian substitutes, and sauces served, which can be found in appendix Table A.3. ${ }^{29}$ Those standard portions were used as inputs into the calculations. Emissions of the raw inputs measured in $\mathrm{CO}_{2} \mathrm{e}$ per kg were taken from Bryngelsson et al. (2016) and Röös (2014) and can be found in appendix Table A.4. As different types of meat differ in emissions per kg, it is important to account for the frequency of different types of meat served within a period. Similarly, vegetarian industry substitutes such as Quorn or soy products have considerably higher emissions than vegetables, eggs, legumes, or grains, which might otherwise be used to substitute for meat. The daily menus of the treated restaurant were used to identify the frequency of each type of meat or vegetarian substitute served during each period and can be found in appendix Table A.1.

Using the standard portions, the emissions values for the inputs, and the menus, emissions calculations were done in four steps: First, emissions of standard portions were calculated separately for dishes containing different kinds of meat and vegetarian substitutes. ${ }^{30}$ The resulting emissions in $\mathrm{kg} \mathrm{CO}_{2} \mathrm{e}$ of each standard portion can be found in Table 9. Second, predicted sales shares for the three alternatives with and without treatment were taken from the nested logit regressions in section 4.5 (see Table 10). Third, emissions for each period were calculated by using the average number of customers per day, the total length of the period, the number of times each type of meat or vegetarian substitute was served, and the predicted sales share of each dish. Finally, expected emissions for periods 1 and 2 were calculated as if

\footnotetext{
${ }^{28}$ When testing for heterogeneous effects of the treatment depending on the type of meat served in an OLS regression, none of the effects are significant at a 5 percent level. The interaction effect for chicken is positive and significant at a 10 percent level in the regression modelling the sales share of meat 1 dishes as the dependent variable. Full regression results are available from the author on request.

${ }^{29}$ As detailed recipes of all the dishes served could not be obtained, exact emissions calculations are impossible.

${ }^{30}$ Emissions values for carbohydrates, vegetables, and sauce were calculated by taking the average of all available values and do not differ between the meat and vegetarian dishes. With respect to the input of dairy products, the chef stated that the vegetarian meals contain less dairy than the meat dishes because he tries to keep many dishes vegan. As he could not quantify the difference, equal inputs of dairy for all dish types were assumed.
} 
there had been no treatment in period 1 using the same input values as in step three, but using the predicted customer shares without treatment.

Table 9. $\mathrm{CO}_{2}$ e emissions of standard portions

\begin{tabular}{|c|c|c|c|c|c|c|c|c|}
\hline & \multicolumn{6}{|c|}{ Standard portions containing meat or fish } & \multicolumn{2}{|c|}{$\begin{array}{l}\text { Vegetarian standard } \\
\text { portions }\end{array}$} \\
\hline Main component & Fish Pork & Beef & Poultry & $\begin{array}{l}\text { Other } \\
\text { meat }\end{array}$ & $\begin{array}{l}\text { Only high- } \\
\text { emitting meats }^{a}\end{array}$ & $\begin{array}{l}\text { Only low- } \\
\text { emitting meats }\end{array}$ & $\begin{array}{l}\text { Veg. } \\
\text { substitute }\end{array}$ & $\begin{array}{l}\text { No sub- } \\
\text { stitute }\end{array}$ \\
\hline $\begin{array}{l}\text { Emissions (kg } \\
\left.\mathrm{CO}_{2} \mathrm{e}\right)\end{array}$ & $1.06 \quad 1.56$ & 7.46 & 0.97 & 4.16 & 7.06 & 1.20 & 0.99 & 0.65 \\
\hline
\end{tabular}

${ }^{a}$ Includes only ruminant meats (beef and mutton).
${ }^{b}$ Includes only nonruminant meats (pork, poultry, and fish).

Results of the calculations are shown in Table 10. Scenario 1 compares emissions in period 1 (from step three) with expected emissions if the nudge had not been in place (from step four) using the point estimates of the treatment effect. Emissions with the nudge in place were 4.8 percent lower than they would have been without the intervention. During the reversal period, emissions were still 3.8 percent lower than they would have been if there had been no intervention in period 1 . This relatively high reduction in emissions compared with the size of the treatment effect can be explained by the fact that during period 2, high-emitting meat such as beef was part of the meat 1 dish more often than during period 1 , while the opposite was the case for the meat 2 dish. So although the share of meat dishes sold increased during the reversal period compared with the treatment period, emissions did not increase to the same extent, as customers substituted between the two meat dishes. This shows that not only demand, but also what is offered, drives emissions.

To explore the sensitivity of the emissions reductions with respect to the size of the treatment effect, scenarios 2 and 3 use the lower and upper bounds of the estimated effect as given by the 95 percent confidence interval. Total emissions are reduced by 0.7 and 8.5 percent, respectively, in those scenarios. The importance of the kind of meats served for GHG emissions is further explored in appendix Table A.5. Scenario 4 eliminates the impact of the changing menu on emissions by using the average menu composition across the whole year for calculating emissions in periods 1 and 2 (see the last column of appendix Table A.5). Using such an average menu results in emissions reductions of 5.4 percent in period 1 and 3 percent in period 2, showing that results heavily depend on the types of meat offered. Scenario 5 assumes that all meat served is ruminant meat (beef and mutton), which is high in $\mathrm{CO}_{2} \mathrm{e}$ emissions per kg. If the nudge were applied on such a menu (all other things equal), emissions reductions would be larger (6.4 percent in period 1 and 3.6 percent in period 2). On the other 
hand, if the menu is already "climate-friendly" and only pork, poultry, and fish are served as the meat dishes, the reduction potential of the nudge is smaller (2.9 and 1.9 percent). ${ }^{31}$

It should be noted that the relatively high reductions in GHG emissions found in the simulation are partly driven by the assumption that cheese was not substituted for meat. As Chen et al. (2016) show, substituting cheese for meat significantly decreases the reduction potential of vegetarian food and in some cases (if climate-friendly meats such as chicken or pork are substituted away from) might even lead to an increase in GHG emissions. In the present case, the chef stated that vegetarian dishes did not contain more cheese than in the meat dishes, but the GHG reduction potential of nudging toward vegetarian diets heavily depends on the kind of vegetarian food served at the restaurant in question.

Looking at the demand elasticities of meat can provide an idea about the price changes necessary to achieve reductions in demand comparable to those from the nudge, and hence about climate change mitigation costs. Estimated own-price elasticities in Sweden are -0.538 for beef, -0.370 for pork, and -0.363 for chicken (Säll and Gren, 2015). Thus a 6 percent reduction in demand would require price increases by 12 to 16 percent.

\footnotetext{
${ }^{31}$ In terms of absolute reductions, scenario 1 shows that the nudge reduced emissions by a total of $1.77 \mathrm{tCO}_{2} \mathrm{e}$. This corresponds approximately to the emissions of driving a car for 11,056 km in Sweden, based on the average $\mathrm{CO}_{2}$ emissions of the car fleet $(160 \mathrm{~g} / \mathrm{km}$ in 2015; see Swedish Traffic Agency, 2016).
} 


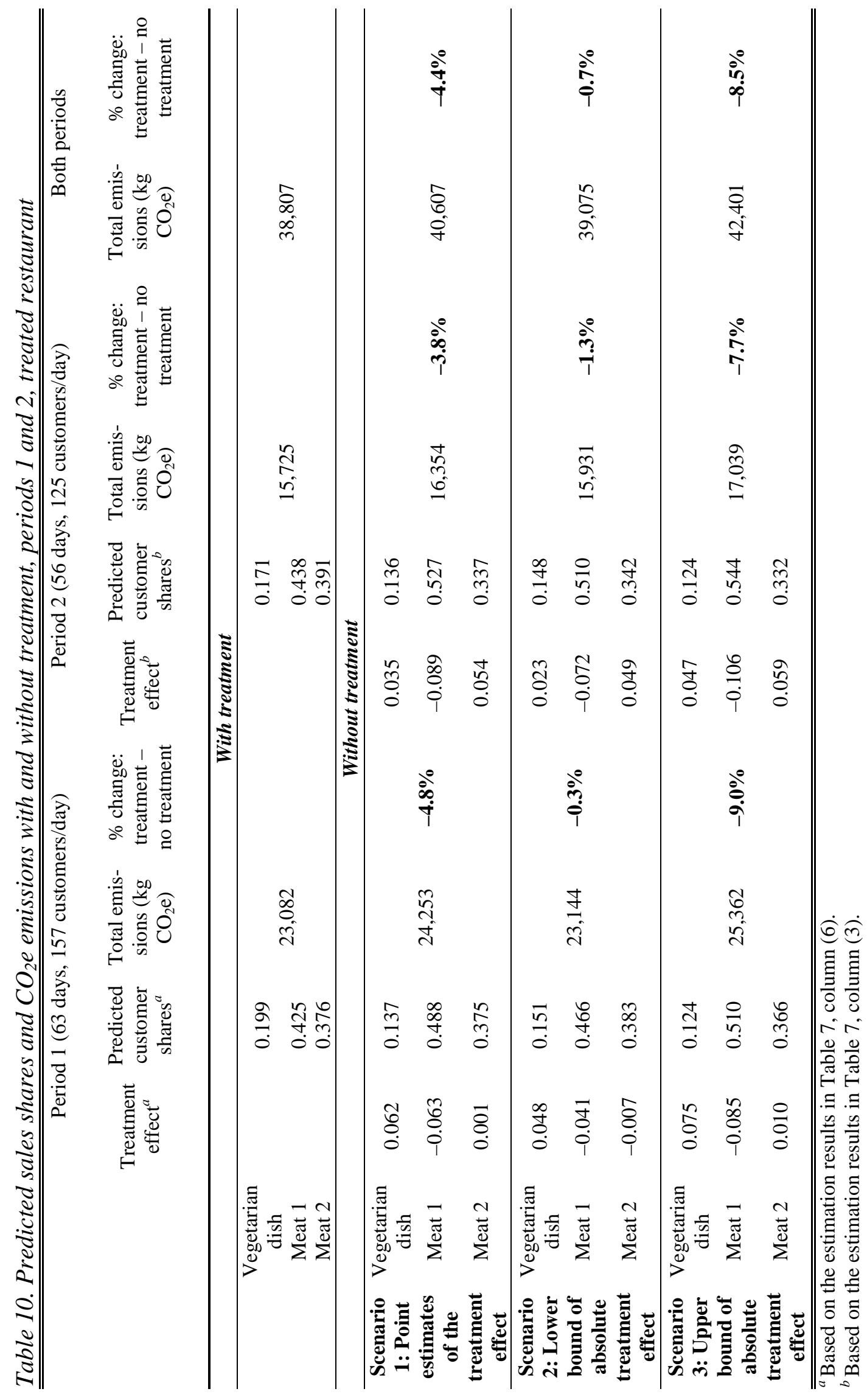




\section{Conclusion}

The results of the field experiment show that it is possible to nudge consumers into more climate-friendly diets. Making the vegetarian dish more salient by increasing its visibility and changing the menu order increased its sales share by around 6 percentage points, which constitutes an increase of around 40 percent of the sales share of the vegetarian dish compared with the baseline period. Although it is not possible to separate the impact of the two changes that were made simultaneously, the analysis of menu order changes at the control restaurant points toward both playing a role in the increase in sales shares. Analyzing the development of the effect over time and the effect of the restoration of the original setup shows that nudging can lead to persistent changes in behavior. This is the first study providing evidence that nudging can have a significant impact on what people eat well into the future, with the share of vegetarian dishes sold remaining about 4 percentage points higher after the intervention was ended. Testing for individual habit formation is not possible with the type of data collected from this experiment but is an important area for future research. The experiment also shows that the intervention affected consumption of all three options on the menu, although at both the treated and the control restaurants, only two dishes were subject to changes in the decision environment. The possibility of such unexpected consequences should be carefully considered when designing nudges, not only in the food domain. Although it is not possible to analyze the effect of the nudge on total sales, it should be mentioned that the restaurant permanently changed its setup to the nudge condition during the academic year 2016-17, indicating that it does not expect a negative impact on profits from changing the decision environment.

How does the nudge compare with other interventions targeted at reducing meat consumption? One such intervention is the establishment of mandatory vegetarian days in public catering. Lombardini and Lankoski (2013) study such a vegetarian day at public schools in Finland. They find that even though its introduction had positive spillover effects on parts of the population, such that they increased their consumption of vegetarian food even on other days, it also caused noncompliance in the form of less food taken and higher plate waste on the vegetarian days. The authors conclude that setting appropriate default choices might be a better option to increase the consumption of vegetarian food than restricting choices. Another type of intervention is environmental labelling of food. Although such labelling usually does not target meat consumption directly, meat products often do worse in environmental assessment. In a test of an environmental label in an experimental supermarket by Vlaeminck et al. 
(2014), the share of meat products dropped by around 20 percent in their most effective treatment. Climate labelling of meals has been tested by Visschers and Siegrist (2015), who find that marking the two most climate-friendly choices out of four meals at a university restaurant led to a 20 percent higher share of climate-friendly choices.

With respect to policy recommendations, the external validity of the results has to be reflected. The restaurant where the nudge was implemented is frequented by a highly educated, rather young population consisting of university students and employees. Younger people might be more open to trying new types of food, and the nudge used here may have a smaller effect in a setting with an older population. On the other hand, data from the Swedish National Food Agency (2012) show that meat consumption is as high amongst people 18-30 years old as it is in the rest of the adult population, and that there are no differences in meat consumption with regard to educational level. Thus the potential for reducing meat consumption through nudging in the Swedish population seems to be equally high across ages and educational levels. Comparing Sweden with other countries with respect to willingness to reduce meat consumption is difficult, but according to a WWF (2016) survey, vegetarian food generally has a positive image in this country, as 30 percent of the respondents associate vegetarian food mainly with healthy eating. Such an association could increase the effectiveness of the nudge. Vetter and Kutzner (2016) do not find an interaction between environmental attitudes and the strength of green default effects in a hypothetical choice situation, but how attitudes and nudges for environmentally friendly food choices interact must be left for further research. Policy recommendations from the present experiment are therefore limited to the fact that it is possible to reduce meat consumption through effective and inexpensive behavioral interventions. Which specific intervention should be chosen depends on the characteristics of the restaurant. The case examined in this study offered good opportunities for nudging, as it was possible to change both the visibility of the vegetarian dish and the menu order simultaneously.

Finally, when considering nudging as a tool for changing consumption patterns, one should keep in mind possible ethical objections against nudging. Recent years have seen a lively and controversial debate on policy-making based on behavioral insights. Many feel that transparency is important for the use of nudging to be acceptable (see, for example, Hansen and Jespersen, 2013). Restaurants and policy-makers who want to use nudges to reduce the climate impact of food consumption should try to do so as transparently as possible. For example, if changes are made to the food environment in a faculty restaurant similar to the one in this 
study, transparency could be increased by informing customers via the weekly menu email that many subscribe to or by putting an appropriate note on the menus set up in the restaurant.

Although simulations such as conducted by Springman et al. (2016) show large potential health benefits at the population level of switching to vegetarian diets, these results are based on assuming varied and nutritionally balanced vegetarian diets substituting omnivorous diets. This assumption might not be fulfilled in every diner where nudging can be applied. In the present case, the restaurants work with nutrition standards that are supposed to be met by all three warm dish alternatives, so we do not any negative impacts on the nutrient supply.

With respect to the environmental significance of the results, it should be pointed out that this paper studies just one of the many food decisions people make every day. Although lunch constitutes one of the larger meals of the day, it is possible that consumers compensate for having chosen vegetarian later during the day. Future research should address such compensation effects, which are important when evaluating not only food nudges, but also nudges for the environment in general. Back-of-the-envelope calculations on the climate impact of the nudge show that emissions from the restaurant's sales decreased by around 5 percent during the intervention period, compared with a scenario without the nudge being implemented. As the nudge was costless for the restaurant to implement and did not affect profits negatively, this paper shows that nudging is a promising tool to foster more climate-friendly food choices. 


\section{References}

Allcott, H., 2011. Social norms and energy conservation. Journal of Public Economics, Special Issue: The Role of Firms in Tax Systems 95, 1082-1095.

doi:10.1016/j.jpubeco.2011.03.003.

Allcott, H., Rogers, T., 2014. The short-run and long-run effects of behavioral interventions: Experimental Evidence from Energy Conservation. American Economic Review 104, 3003-3037. doi:10.1257/aer.104.10.3003.

Angrist, J.D., Pischke, J.-S., 2008. Mostly Harmless Econometrics: An Empiricist’s Companion. Princeton University Press, New Jersey.

Becker, G.S., Murphy, K.M., 1988. A theory of rational addiction. Journal of Political Economy 96, 675-700.

Belot, M., James, J., Nolen, P.J., 2015. Incentives and Children’s Dietary Choices: A Field Experiment in Primary Schools (IZA Discussion Paper No. 9424). Institute for the Study of Labor (IZA).

Brandon, A., Ferraro, P.J., List, J.A., Metcalfe, R.D., Price, M.K., Rundhammer, F., 2017. Do The Effects of Social Nudges Persist? Theory and Evidence from 38 Natural Field Experiments (No. w23277). National Bureau of Economic Research.

Bryngelsson, D., Wirsenius, S., Hedenus, F., Sonesson, U., 2016. How can the EU climate targets be met? A combined analysis of technological and demand-side changes in food and agriculture. Food Policy 59, 152-164. doi:10.1016/j.foodpol.2015.12.012.

Carney, D.R., Banaji, M.R., 2012. First is best. PLOS ONE 7, e35088. doi:10.1371/journal.pone.0035088.

Chen, D.M., Tucker, B., Badami, M.G., Ramankutty, N., Rhemtulla, J.M., 2016. A multidimensional metric for facilitating sustainable food choices in campus cafeterias. Journal of Cleaner Production 135, 1351-1362. doi:10.1016/j.jclepro.2016.06.143.

Cohen, D., Farley, T.A., 2007. Eating as an automatic behavior. Preventing Chronic Disease 5.

Croson, R., Treich, N., 2014. Behavioral environmental economics: Promises and challenges. Environmental and Resource Economis 58, 335-351. doi:10.1007/s10640-014-9783y.

Daunfeldt, S.-O., Nordström, J., Thunström, L., 2011. Habit Formation in Food Consumption. In: The Oxford Handbook on the Economics of Food Consumption and Policy. Oxford University Press.

Dayan, E., Bar-Hillel, M., 2011. Nudge to nobesity II: Menu positions influence food orders. Judgment and Decision Making 6, 333-342.

Egebark, J., Ekström, M., 2016. Can indifference make the world greener? Journal of Environmental Economics and Management 76, 1-13. doi:10.1016/j.jeem.2015.11.004.

Feenberg, D.R., Ganguli, I., Gaule, P., Gruber, J., 2015. It’s Good to Be First: Order Bias in Reading and Citing NBER Working Papers (Working Paper No. 21141). National Bureau of Economic Research.

Ferraro, P.J., Miranda, J.J., Price, M.K., 2011. The persistence of treatment effects with normbased policy instruments: Evidence from a randomized environmental policy experiment. American Economic Review 101, 318-22. doi:10.1257/aer.101.3.318. 
Ferraro, P.J., Price, M.K., 2013. Using nonpecuniary strategies to influence behavior: Evidence from a large-scale field experiment. Review of Economics and Statistics 95, 6473. doi:10.1162/REST_a_00344.

Gerber, P.J., Steinfeld, H., Henderson, P., Mottet, A., Opio, C., Dijkman, J., Falcuci, A., Tempio, G., 2013. Tackling Climate Change through Livestock: A Global Assessment of Emissions and Mitigation Opportunities. Food and Agriculture Organization of the United Nations (FAO), Rome.

Girod, B., van Vuuren, D.P., Hertwich, E.G., 2014. Climate policy through changing consumption choices: Options and obstacles for reducing greenhouse gas emissions. Global Environmental Change 25, 5-15. doi:10.1016/j.gloenvcha.2014.01.004.

Gneezy, U., Meier, S., Rey-Biel, P., 2011. When and why incentives (don’t) work to modify behavior. Journal of Economic Perspectives 25, 191-210. doi:10.1257/jep.25.4.191.

Hansen, P.G., Jespersen, A.M., 2013. Nudge and the manipulation of choice: A framework for the responsible use of the nudge approach to behaviour change in public policy. European Journal of Risk Regulation 4, 3.

Hunt, G.L., 2000. Alternative nested logit model structures and the special case of partial degeneracy. Journal of Regional Science 40, 89-113. doi:10.1111/0022-4146.00166.

Jaime Torres, M.M., Carlsson, F., 2016. Social Norms and Information Diffusion in Watersaving Programs: Evidence from a Randomized Field Experiment in Colombia. No. 652, Working Papers in Economics, University of Gothenburg, Department of Economics.

Jones, C.M., Kammen, D.M., 2011. Quantifying carbon footprint reduction opportunities for U.S. households and communities. Environmental Science and Technology 45, 40884095. doi:10.1021/es102221h.

Just, D.R., 2009. Smarter lunchrooms: Using behavioral economics to improve meal selection. CHOICES 24, 1.

Just, D.R., Price, J., 2013. Using incentives to encourage healthy eating in children. Journal of Human Resources 48, 855-872. doi:10.3368/jhr.48.4.855.

Kahneman, D., 2003. Maps of bounded rationality: Psychology for behavioral economics. American Economic Review 93, 1449-1475.

Kahneman, D., 2011. Thinking, Fast and Slow. Farrar, Straus and Giroux, New York.

Lehner, M., Mont, O., Heiskanen, E., 2016. Nudging: A promising tool for sustainable consumption behaviour? Journal of Cleaner Production 134, 166-177. doi:10.1016/j.jclepro.2015.11.086.

List, J.A., Samek, A.S., 2015. The behavioralist as nutritionist: Leveraging behavioral economics to improve child food choice and consumption. Journal of Health Economics 39, 135-146. doi:10.1016/j.jhealeco.2014.11.002.

List, J.A., Samek, A., 2017. A field experiment on the impact of incentives on milk choice in the lunchroom. Public Finance Review 45, 44-67. doi:10.1177/1091142115602061.

Loewenstein, G., Price, J., Volpp, K., 2016. Habit formation in children: Evidence from incentives for healthy eating. Journal of Health Economics 45, 47-54.

doi:10.1016/j.jhealeco.2015.11.004. 
Löfgren, Å., Martinsson, P., Hennlock, M., Sterner, T., 2012. Are experienced people affected by a pre-set default option-Results from a field experiment. Journal of Environmental Economics and Management 63, 66-72. doi:10.1016/j.jeem.2011.06.002.

Lombardini, C., Lankoski, L., 2013. Forced choice restriction in promoting sustainable food consumption: Intended and unintended effects of the mandatory vegetarian day in Helsinki schools. Journal of Consumer Policy 36, 159-178. doi:10.1007/s10603-0139221-5.

Lusk, J.L., 2014. Are you smart enough to know what to eat? A critique of behavioural economics as justification for regulation. European Review of Agricultural Economics 41, 355-373. doi:10.1093/erae/jbu019.

Machovina, B., Feeley, K.J., 2014. Taking a bite out of biodiversity. Science 343, 838-838. doi:10.1126/science.343.6173.838-a.

Mantonakis, A., Rodero, P., Lesschaeve, I., Hastie, R., 2009. Order in choice effects of serial position on preferences. Psychological Science 20, 1309-1312. doi:10.1111/j.14679280.2009.02453.x.

Marteau, T.M., Hollands, G.J., Fletcher, P.C., 2012. Changing human behavior to prevent disease: The importance of targeting automatic processes. Science 337, 1492-1495. doi:10.1126/science.1226918.

Miller, J.M., Krosnick, J.A., 1998. The impact of candidate name order on election outcomes. Public Opinion Quarterly 62, 291-330.

Naik, N.Y., Moore, M.J., 1996. Habit formation and intertemporal substitution in individual food consumption. Review of Economics and Statistics 78, 321-328. doi:10.2307/2109934.

Naturvårdsverket, 2011. Köttkonsumtionens klimatpåverkan. Drivkrafter och styrmedel. (Rapport No. 6456). Naturvårdsverket, Stockholm.

Painter, J.E., Wansink, B., Hieggelke, J.B., 2002. How visibility and convenience influence candy consumption. Appetite 38, 237-238. doi:10.1006/appe.2002.0485.

Pelletier, N., Tyedmers, P., 2010. Forecasting potential global environmental costs of livestock production 2000-2050. PNAS 107, 18371-18374. doi:10.1073/pnas.1004659107.

Pimentel, D., Pimentel, M., 2003. Sustainability of meat-based and plant-based diets and the environment. American Journal of Clinical Nutrition 78, 660S-663S.

Policastro, P., Smith, Z., Chapman, G., 2015. Put the healthy item first: Order of ingredient listing influences consumer selection. Journal of Health Psychology 22, 853-863. doi:10.1177/1359105315617328.

Puhani, P.A., 2012. The treatment effect, the cross difference, and the interaction term in nonlinear "difference-in-differences" models. Economics Letters 115, 85-87. doi:10.1016/j.econlet.2011.11.025.

Röös, E., 2014. Mat-klimat-listan (Report No. 77). Uppsala.

Rozin, P., Scott, S., Dingley, M., Urbanek, J.K., Jiang, H., Kaltenbach, M., 2011. Nudge to nobesity I: Minor changes in accessibility decrease food intake. Judgment and Decision Making 6, 323-332. 
Säll, S., Gren, I.-M., 2015. Effects of an environmental tax on meat and dairy consumption in Sweden. Food Policy 55, 41-53. doi:10.1016/j.foodpol.2015.05.008.

Schösler, H., Boer, J. de, Boersema, J.J., 2012. Can we cut out the meat of the dish? Constructing consumer-oriented pathways towards meat substitution. Appetite 58, 39-47. doi:10.1016/j.appet.2011.09.009.

Shewmake, S., Okrent, A., Thabrew, L., Vandenbergh, M., 2015. Predicting consumer demand responses to carbon labels. Ecological Economics 119, 168-180. doi:10.1016/j.ecolecon.2015.08.007.

Springmann, M., Godfray, H.C.J., Rayner, M., Scarborough, P., 2016. Analysis and valuation of the health and climate change cobenefits of dietary change. PNAS 113, 4146-4151. doi:10.1073/pnas.1523119113.

Sunstein, C.R., 2015. Behavioural economics, consumption and environmental protection. In: Reisch, L.A., Thøgersen, J. (Eds.), Handbook of Research on Sustainable Consumption. Edward Elgar Publishing, pp. 313-327.

Swedish Agricultural Board, 2017. Förbrukningen av kött och ägg nådde ny rekordnivå 2016 - Jordbruksverket.

http://www.jordbruksverket.se/amnesomraden/handelmarknad/nyheteromhandel/nyhet eromhan-

del2017/forbrukningenavkottochaggnaddenyrekordniva2016.5.6132fce715aa03fa7ec2 817c.html (accessed 3.22.17).

Swedish National Food Agency, 2012. Riksmaten 2010 - 11. Livsmedels- och näringsintag bland vuxna i Sverige. Uppsala.

Swedish National Food Agency, 2015. Swedish dietary guidelines: Risk and benefit management report, Livsmedelsverkets rapportserie nr 5/2015. Livsmedelsverket.

Swedish Traffic Agency (Trafikverket), 2016. Emissions from road traffic (Vägtrafikens utsläpp). Press release. Borlänge.

Thaler, R.H., Sunstein, C.R., 2008. Nudge: Improving Decisions about Health, Wealth, and Happiness. Yale University Press, New Haven.

Tilman, D., Clark, M., 2014. Global diets link environmental sustainability and human health. Nature 515, 518-522. doi:10.1038/nature13959.

Vetter, M., Kutzner, F., 2016. Nudge me if you can: How defaults and attitude strength interact to change behavior. Comprehensive Results in Social Psychology, 1-27. doi:10.1080/23743603.2016.1139390.

Visschers, V.H.M., Siegrist, M., 2015. Does better for the environment mean less tasty? Offering more climate-friendly meals is good for the environment and customer satisfaction. Appetite 95, 475-483. doi:10.1016/j.appet.2015.08.013.

Vlaeminck, P., Jiang, T., Vranken, L., 2014. Food labeling and eco-friendly consumption: Experimental evidence from a Belgian supermarket. Ecological Economics 108, 180 190. doi:10.1016/j.ecolecon.2014.10.019.

Wansink, B., Hanks, A.S., 2013. Slim by design: Serving healthy foods first in buffet lines improves overall meal selection. PLOS ONE 8, e77055.

doi:10.1371/journal.pone.0077055. 
Wansink, B., Love, K., 2014. Slim by design: Menu engineering strategies for promoting high-margin, healthy foods. International Journal of Hospitality Management 42, 137143. doi:10.2139/ssrn.2467777.

Wansink, B., Painter, J.E., Lee, Y.-K., 2006. The office candy dish: Proximity’s influence on estimated and actual consumption. International Journal of Obesity 30, 871-875. doi:10.1038/sj.ijo.0803217.

Wansink, B., Sobal, J., 2007. Mindless eating: The 200 daily food decisions we overlook. Environment and Behavior 39, 106-123. doi:10.1177/0013916506295573.

Westhoek, H., Lesschen, J.P., Rood, T., Wagner, S., De Marco, A., Murphy-Bokern, D., Leip, A., van Grinsven, H., Sutton, M.A., Oenema, O., 2014. Food choices, health and environment: Effects of cutting Europe's meat and dairy intake. Global Environmental Change 26, 196-205. doi:10.1016/j.gloenvcha.2014.02.004.

Wirsenius, S., Hedenus, F., Mohlin, K., 2011. Greenhouse gas taxes on animal food products: rationale, tax scheme and climate mitigation effects. Climatic Change 108, 159-184. doi:10.1007/s10584-010-9971-X.

Wisdom, J., Downs, J.S., Loewenstein, G., 2010. Promoting healthy choices: Information versus convenience. American Economic Journal: Applied Economics 2, 164-178. doi:10.1257/app.2.2.164.

WWF, 2016. Världsnaturfonden WWF - WWFs klimatundersökning 2016: Svenskarna vill minska på köttet. Världsnaturfonden WWF.

http://www.wwf.se/show.php?id=1632075 (accessed 3.28.17). 


\title{
Appendix
}

Figure A.1. Example menus from treated restaurant, period 0 and period 1 Måndag

Örtbakat kycklinglår med tzatziki samt ris

Provencalsk lökpaj med tomat och mozzarella

Tisdag

Pasta med rókt sidfläsk, kvibille ädelostas och orrtrostade solroskärnor

\author{
Ugnsbakad sejfilé med vitvin- \& gräslökssås \\ Curry-och kokoswokade nudlar med quorn och grönsaker \\ Lammiarsbiff med rostad blomkal och splskummin samt gula ärtor med mejram \\ och lök \\ Onsdag \\ Lăttrimmad ugnsbakad lax med sojacremefraiche samt grönsaksris \\ Spaghetti med rostad paprikasås, råmarinerad zucchini samt grana padano \\ Stekt fläsk med löksås samt kokt potatis \\ Torsdag \\ Boeuf Bourguignon - långkokt högrev med svamp, smålök och med sidfläsk \\ Böngulasch med ris och crème fraiche \\ pulled pork serveras med tomat- och mangosalsa, gräddfil och ris \\ Boston och chiligratinerad falukorv med potatismos \\ Tagliatelle med quornfärssắs samt Grana Padano \\ Stekt kycklingbröst med mango- och grönsaksyoghurt samt ris \\ Lunch med salladsbuffé, dressing, bröd \& smör 70 kr | Komplett lunch inkl. kaffe 75 kr \\ Soppa - inklusive salladsbuffé, bröd \& smör 50:- Endast soppa 35:- \\ Goda sallader från 30 kr
}

\begin{tabular}{|c|c|}
\hline Måndag & $\begin{array}{l}\text { Tagliatelle med grönärtpesto och mynta } \\
\text { Rosmarinstekt kycklingbröst med äpple, sherrysås samt ris } \\
\text { Basilikabakad laxfilé med tomatgräddsås samt kokt potatis }\end{array}$ \\
\hline \multirow[t]{2}{*}{ Tisdag } & \\
\hline & $\begin{array}{l}\text { Spenatlasagne med getost och rostade solroskärnor } \\
\text { Katalansk högrevsgryta med chorizo, oliver och tomat samt kokt } \\
\text { potatis } \\
\text { Fläskköttswok med thaibasilika, sweet chiliyoghurt och basmatiris }\end{array}$ \\
\hline \multicolumn{2}{|l|}{ Onsdag } \\
\hline & $\begin{array}{l}\begin{array}{l}\text { Cannelloni med matvete och champinjoner samt spenatsallad } \\
\text { toppad med solroskärnor }\end{array} \\
\text { Stekt pannbiff med rödlök- och balsamicosmör, löksky samt kokt } \\
\text { potatis } \\
\text { Smörstekt sej med syrlig gurksallad och pepparrotsyoghurt } \\
\text { serveras med kokt potatis }\end{array}$ \\
\hline \multicolumn{2}{|r|}{ 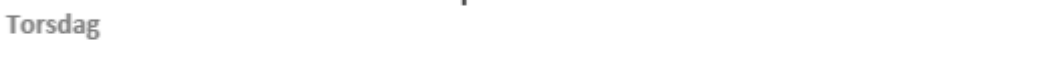 } \\
\hline & $\begin{array}{l}\text { Ärtsoppa med pannkakor samt sylt och grädde } \\
\text { Baconlindad chorizo med kryddig paprikarelish och potatismos } \\
\text { Vitlöksmarinerad kycklingklubba med currycoleslaw samt rostade } \\
\text { rotsaker }\end{array}$ \\
\hline Fredag & $\begin{array}{l}\text { Kikärtscurry med kokos och koriander samt ris } \\
\text { Sprödbakad torsk med remouladsảs och kokt potatis samt citron } \\
\text { Timjan \& fänkålsstekt fläskkarré med plommon och balsamicosås } \\
\text { samt rostad klyft potatis }\end{array}$ \\
\hline
\end{tabular}

Note: The vegetarian option is highlighted by a frame, which was added by the author and not part of the original menu. 
Table A.1. Menu composition of the two restaurants across periods

\begin{tabular}{|c|c|c|c|c|c|c|c|c|}
\hline \multirow{3}{*}{ Type of dish } & \multicolumn{2}{|c|}{ Period 0} & \multicolumn{2}{|c|}{ Period 1} & \multicolumn{2}{|c|}{ Period 2} & \multicolumn{2}{|c|}{ All year } \\
\hline & $\begin{array}{l}\text { \# of days } \\
\text { served }\end{array}$ & $\begin{array}{l}\text { share } \\
\text { of days }\end{array}$ & $\begin{array}{l}\text { \# of days } \\
\text { served }\end{array}$ & $\begin{array}{l}\text { share of } \\
\text { days }\end{array}$ & $\begin{array}{l}\text { \# of days } \\
\text { served }\end{array}$ & $\begin{array}{l}\text { share } \\
\text { of days }\end{array}$ & $\begin{array}{l}\text { \# of days } \\
\text { served }\end{array}$ & $\begin{array}{l}\text { share } \\
\text { of days }\end{array}$ \\
\hline & & & & & & & & \\
\hline \multicolumn{9}{|c|}{ Treated Restaurant } \\
\hline \multicolumn{9}{|l|}{ Vegetarian } \\
\hline Other vegetarian & 8 & 0.17 & 10 & 0.16 & 10 & 0.18 & 28 & 0.17 \\
\hline Pasta & 8 & 0.17 & 11 & 0.175 & 8 & 0.14 & 27 & 0.16 \\
\hline Patty & 5 & 0.11 & 9 & 0.14 & 15 & 0.27 & 29 & 0.17 \\
\hline Stew & 7 & 0.15 & 11 & 0.175 & 9 & 0.16 & 27 & 0.16 \\
\hline Vegetables & 9 & 0.19 & 7 & 0.11 & 8 & 0.14 & 24 & 0.14 \\
\hline World & 7 & 0.15 & 7 & 0.11 & 5 & 0.09 & 19 & 0.11 \\
\hline Soup & 3 & 0.06 & 8 & 0.13 & 1 & 0.02 & 12 & 0.07 \\
\hline Total & 47 & 1.00 & 63 & 1.00 & 56 & 1.00 & 166 & 1.00 \\
\hline \multicolumn{9}{|l|}{ Processed substitute } \\
\hline (Quorn, tofu, soy) $^{a}$ & 4 & 0.09 & 3 & 0.05 & 4 & 0.07 & 11 & 0.06 \\
\hline Other substitute $^{a}$ & 43 & 0.91 & 60 & 0.95 & 52 & 0.93 & 155 & 0.94 \\
\hline \multicolumn{9}{|l|}{ Meat 1 dish } \\
\hline Beef & 13 & 0.28 & 10 & 0.16 & 9 & 0.16 & 32 & 0.19 \\
\hline Chicken & 9 & 0.19 & 12 & 0.19 & 7 & 0.12 & 28 & 0.17 \\
\hline Fish & 12 & 0.26 & 20 & 0.32 & 19 & 0.34 & 51 & 0.31 \\
\hline Other meat & 10 & 0.21 & 9 & 0.14 & 10 & 0.18 & 29 & 0.17 \\
\hline Pork & 3 & 0.06 & 9 & 0.14 & 9 & 0.16 & 21 & 0.13 \\
\hline Soup & 0 & 0 & 3 & 0.05 & 2 & 0.04 & 5 & 0.03 \\
\hline Total & 47 & 1.00 & 63 & 1.00 & 56 & 1.00 & 166 & 1.00 \\
\hline \multicolumn{9}{|l|}{ Meat 2 dish } \\
\hline Beef & 6 & 0.13 & 10 & 0.16 & 5 & 0.09 & 21 & 0.13 \\
\hline Chicken & 8 & 0.17 & 7 & 0.11 & 18 & 0.32 & 33 & 0.20 \\
\hline Fish & 12 & 0.26 & 17 & 0.27 & 12 & 0.22 & 41 & 0.25 \\
\hline Other meat & 11 & 0.23 & 15 & 0.24 & 13 & 0.23 & 39 & 0.23 \\
\hline Pork & 10 & 0.21 & 14 & 0.22 & 8 & 0.14 & 32 & 0.19 \\
\hline \multirow[t]{2}{*}{ Total } & 47 & 1.00 & 63 & 1.00 & 56 & 1.00 & 166 & 1.00 \\
\hline & \multicolumn{8}{|c|}{ Control Restaurant } \\
\hline \multicolumn{9}{|l|}{ Vegetarian } \\
\hline Other vegetarian & 12 & 0.25 & 11 & 0.16 & 6 & 0.11 & 29 & 0.16 \\
\hline Pasta & 7 & 0.14 & 8 & 0.11 & 8 & 0.15 & 23 & 0.13 \\
\hline Patty & 10 & 0.20 & 16 & 0.22 & 9 & 0.17 & 35 & 0.20 \\
\hline Stew & 11 & 0.23 & 16 & 0.22 & 13 & 0.24 & 40 & 0.23 \\
\hline Vegetables & 5 & 0.08 & 15 & 0.21 & 12 & 0.12 & 31 & 0.18 \\
\hline World & 5 & 0.10 & 6 & 0.08 & 6 & 0.11 & 17 & 0.10 \\
\hline Total & 49 & 1.00 & 72 & 1.00 & 54 & 1.00 & 175 & 1.00 \\
\hline \multicolumn{9}{|l|}{ Meat 1 dish } \\
\hline Beef & 5 & 0.10 & 5 & 0.07 & 5 & 0.09 & 15 & 0.09 \\
\hline Chicken & 1 & 0.02 & 5 & 0.07 & 10 & 0.18 & 16 & 0.09 \\
\hline Fish & 17 & 0.35 & 22 & 0.31 & 8 & 0.15 & 47 & 0.27 \\
\hline Other meat & 6 & 0.12 & 13 & 0.18 & 16 & 0.30 & 35 & 0.20 \\
\hline Pork & 10 & 0.21 & 13 & 0.18 & 9 & 0.17 & 32 & 0.18 \\
\hline Soup & 10 & 0.20 & 14 & 0.19 & 6 & 0.11 & 30 & 0.17 \\
\hline Total & 49 & 1.00 & 72 & 1.00 & 54 & 1.00 & 175 & 1.00 \\
\hline \multicolumn{9}{|l|}{ Meat 2 dish } \\
\hline Beef & 11 & 0.23 & 4 & 0.06 & 6 & 0.11 & 21 & 0.12 \\
\hline Chicken & 13 & 0.27 & 19 & 0.26 & 6 & 0.11 & 38 & 0.22 \\
\hline Fish & 6 & 0.12 & 21 & 0.29 & 21 & 0.39 & 48 & 0.275 \\
\hline Other meat & 10 & 0.20 & 18 & 0.25 & 13 & 0.24 & 41 & 0.235 \\
\hline Pork & 9 & 0.18 & 10 & 0.14 & 8 & 0.15 & 27 & 0.15 \\
\hline Total & 49 & 1.00 & 72 & 1.00 & 54 & 1.00 & 175 & 1.00 \\
\hline
\end{tabular}

${ }^{a}$ Used for calculating the climate impact of the intervention but not used in the regressions. 
Table A.2: Heterogeneous effects: Type of vegetarian dish

\begin{tabular}{|c|c|c|c|c|}
\hline $\begin{array}{l}\text { Dependent variable: Share of } \\
\text { vegetarian dishes served }\end{array}$ & $\begin{array}{c}\text { Before-after }+ \\
\text { type }\end{array}$ & $\begin{array}{l}\text { Heterogenous } \\
\text { effects }\end{array}$ & $\begin{array}{c}\text { Basic DiD + } \\
\text { type } \\
\end{array}$ & $\begin{array}{c}\text { Heterogenous } \\
\text { effects }\end{array}$ \\
\hline Period 1 & $\begin{array}{c}0.0703 * * * \\
(0.0122)\end{array}$ & $\begin{array}{c}0.0658 * * \\
(0.0281)\end{array}$ & $\begin{array}{l}-0.0149 \\
(0.0243)\end{array}$ & $\begin{array}{c}-0.00882 \\
(0.0341)\end{array}$ \\
\hline Period 2 & $\begin{array}{c}0.0409 * * * \\
(0.0126)\end{array}$ & $\begin{array}{c}0.0466 \\
(0.0296)\end{array}$ & & \\
\hline Restaurant 1 & & & $\begin{array}{c}-0.138 * * * \\
(0.0134)\end{array}$ & $\begin{array}{c}-0.140 * * * \\
(0.0274)\end{array}$ \\
\hline Rest $1 \times$ Period 1 & & & $\begin{array}{c}0.0730^{* * *} \\
(0.0166)\end{array}$ & $\begin{array}{c}0.0776 * * \\
(0.0378)\end{array}$ \\
\hline Period $1 \times$ Pasta & & $\begin{array}{c}0.0234 \\
(0.0397)\end{array}$ & & \\
\hline Period $1 \times$ Patty & & $\begin{array}{c}0.0502 \\
(0.0440)\end{array}$ & & \\
\hline Period $1 \times$ Stew & & $\begin{array}{l}-0.0389 \\
(0.0413)\end{array}$ & & \\
\hline Period $1 \times$ Vegetables & & $\begin{array}{c}0.0318 \\
(0.0430)\end{array}$ & & \\
\hline Period $1 \times$ Soup & & $\begin{array}{c}0.0140 \\
(0.0496)\end{array}$ & & \\
\hline Period $1 \times$ World & & $\begin{array}{c}-0.0270 \\
0.0234\end{array}$ & & \\
\hline Period $2 \times$ Pasta & & $\begin{array}{l}0.00567 \\
(0.0438)\end{array}$ & & -0.00136 \\
\hline Period $2 \times$ Patty & & $\begin{array}{l}-0.0127 \\
(0.0425)\end{array}$ & & $\begin{array}{c}(0.0554) \\
0.0402\end{array}$ \\
\hline Period $2 \times$ Stew & & $\begin{array}{l}0.00252 \\
(0.0429)\end{array}$ & & $\begin{array}{l}(0.0540) \\
-0.0585\end{array}$ \\
\hline Period $2 \times$ Vegetables & & $\begin{array}{c}0.0196 \\
(0.0431)\end{array}$ & & $\begin{array}{c}(0.0534) \\
0.0717\end{array}$ \\
\hline Period $2 \times$ Soup & & $\begin{array}{c}0.110 \\
(0.0766)\end{array}$ & & $\begin{array}{l}(0.0599) \\
-0.0159\end{array}$ \\
\hline Period $2 \times$ World & & $\begin{array}{r}-0.0796 * \\
(0.0470)\end{array}$ & & $\begin{array}{c}(0.0608) \\
-0.00136 \\
(0.0554)\end{array}$ \\
\hline Constant & $\begin{array}{l}0.154^{* * *} \\
(0.0315)\end{array}$ & $\begin{array}{c}0.156^{* * *} \\
(0.0336)\end{array}$ & $\begin{array}{c}0.320 * * * \\
(0.0353)\end{array}$ & $\begin{array}{l}0.301^{* * *} \\
(0.0382)\end{array}$ \\
\hline Observations & 166 & 166 & 231 & 231 \\
\hline Adj $R$-squared & 0.268 & 0.297 & 0.526 & 0.524 \\
\hline Vegtype & Yes & Yes & Yes & Yes \\
\hline Meattype & Yes & Yes & Yes & Yes \\
\hline Month FE & No & No & Yes & Yes \\
\hline Holiday FE & No & No & Yes & Yes \\
\hline Weekday FE & Yes & Yes & Yes & Yes \\
\hline
\end{tabular}

Note: Including all weeks in period 0 and 1 . The baseline category for the type of vegetarian dish is other vegetarian. The specifications in columns 1 and 3 correspond to the specifications in column 4 of Table 6 and column 8 of Table 4, respectively, and are shown for comparison reasons.

Standard errors in parentheses, $* * * \mathrm{p}<0.01,{ }^{* *} \mathrm{p}<0.05, * \mathrm{p}<0.1$. 
Table A.3. Summary of the input values used for emissions calculations

\begin{tabular}{|c|c|c|c|}
\hline Input category & \multicolumn{2}{|c|}{ Input quantity } & Assumptions regarding $\mathrm{CO}_{2} \mathrm{e}$ emissions \\
\hline & $\begin{array}{l}\text { Meat } \\
\text { dishes }\end{array}$ & $\begin{array}{l}\text { Vegeta- } \\
\text { rian dish }\end{array}$ & \\
\hline $\begin{array}{cl}\text { Meat or fish (raw input): } \\
\text { - } & \text { Beef } \\
\text { - } & \text { Pork } \\
\text { - } & \text { Chicken } \\
\text { - } & \text { Fish } \\
\text { - } & \text { Other meat }\end{array}$ & $160 \mathrm{~g}$ & & $\begin{array}{l}\text { Individual values for beef, chicken, pork } \\
\text { and fish } \\
\text { If category “other meat”: average of the } \\
\text { values for beef, poultry, mutton, and } \\
\text { pork }\end{array}$ \\
\hline $\begin{array}{l}\text { Vegetarian substitute: } \\
\text { - } \\
\text { Processed product (Quorn, or pro- } \\
\text { cessed soy product such as tofu) } \\
\text { - Combination of legumes, potatoes, } \\
\text { vegetables, and eggs }\end{array}$ & & $110 \mathrm{~g}$ & $\begin{array}{l}\text { Processed products (Quorn, soy, tofu): } \\
\text { emissions values from Röös (2014) } \\
\text { Unspecified substitutes: average of the } \\
\text { value for vegetables, legumes, flour, and } \\
\text { potatoes }\end{array}$ \\
\hline $\begin{array}{l}\text { Vegetables } \\
\text { - Combination of cabbage, onions, po- } \\
\text { tatoes, roots, and green vegetables }\end{array}$ & $50 \mathrm{~g}$ & $100 \mathrm{~g}$ & Average of all values for vegetables \\
\hline $\begin{array}{l}\text { Carbohydrates/starch (cooked) } \\
\text { • Combination of rice, potatoes, pas- } \\
\text { ta, other grains, and flour }\end{array}$ & $200 \mathrm{~g}$ & $210 \mathrm{~g}$ & $\begin{array}{l}\text { Average of the values for rice, potatoes, } \\
\text { and pasta }\end{array}$ \\
\hline $\begin{array}{l}\text { Sauce/dairy products } \\
\text { - Combination of liquid dairy, } \\
\text { cheese, butter, and water }\end{array}$ & $100 \mathrm{ml}^{a}$ & $100 \mathrm{ml}^{a}$ & $\begin{array}{l}\text { Average of the values for liquid dairy, } \\
\text { butter, and cheese }\end{array}$ \\
\hline Total weight & $510 \mathrm{~g}$ & $510 \mathrm{~g}$ & \\
\hline
\end{tabular}


Emissions values in $\mathrm{CO}_{2} \mathrm{e} / \mathrm{kg}$ fresh product

Dairy products and eggs

Butter $^{a, d}$

Cheese $^{a}$

Liquid dairy $^{a}$

Average dairy ${ }^{c, d}$

Eggs $^{a}$

Vegetables

Green vegetables $^{a}$

Cabbage, onions $^{a}$

Potatoes, roots ${ }^{a}$

Average vegetables ${ }^{c, e}$

Meat, fish

Fish $^{a}$

Beef $^{a}$

Mutton $^{a}$

Pork $^{a}$

Poultry $^{a}$

Average meat (average of beef, mutton, pork, poultry) ${ }^{c, f}$

Average pork, poulty, fish ${ }^{c, k}$

Carbohydrates

Rice $^{a}$

Pasta $^{a}$

Other grains, flour ${ }^{a}$

Average cereals ${ }^{c}$

Average carbohydrates (cereals + potatoes) ${ }^{c, g}$

Vegetarian substitute products

Vegetable protein from legumes ${ }^{a}$

Average vegetarian substitutes (legumes, carbohydrates,

vegetables, eggs) except processed substitutes ${ }^{c, h}$

Soy meat substitute (tofu, soy sausage, etc) ${ }^{b}$

Quorn $^{b}$

Average processed vegetarian substitutes ${ }^{c, i}$

${ }^{a}$ Source: Bryngelsson et al. (2016).

${ }^{b}$ Source: Röös (2014).

${ }^{c}$ Own calculations, arithmetic mean of the raw input values.

${ }^{d}$ Used as input value for dairy products.

${ }^{e}$ Used as input value for vegetables.

${ }^{f}$ Used as input value for other meat.

${ }^{g}$ Used as input value for carbohydrates.

${ }^{h}$ Used as input value for vegetarian substitute.

${ }^{i}$ Used as input value for processed vegetarian substitute.

${ }^{j}$ Used as input value for high-emitting meats.

${ }^{k}$ Used as input value for low-emitting meats. 


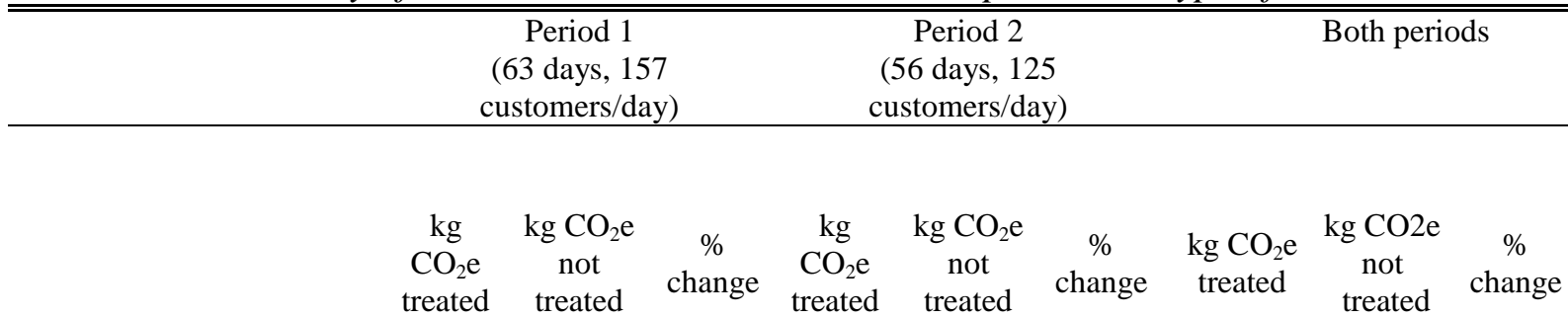

\section{Actually observed com-}

$\begin{array}{llllllllll}\text { position of dishes each } & 23,082 & 24,253 & -4.8 \% & 15,725 & 16,354 & -3.8 \% & 38,807 & 40,607 & -4.4 \%\end{array}$
period (scenario 1)

Scenario 4: Average composition of dishes $23,359 \quad 24,699 \quad-5.4 \% \quad 17,446 \quad 17,980 \quad-3.0 \% \quad 40,805 \quad 42,679 \quad-4.4 \%$ across the whole year ${ }^{a}$

Scenario 5: Only highemitting meats served ${ }^{b}$

$$
\begin{array}{lllllllll}
57,281 & 61,174 & -6.4 \% & 41,772 & 43,328 & -3.6 \% & 99,053 & 104,502 & -5.2 \%
\end{array}
$$

Scenario 6: Only lowemitting meats served ${ }^{c}$

$$
\begin{array}{lllllllll}
10,799 & 11,117 & -2.9 \% & 8,610 & 8,774 & -1.9 \% & 19,409 & 19,891 & -2.4 \%
\end{array}
$$

${ }^{a}$ Instead of using the menu composition each period, the average menu composition was used as given in the last column of appendix Table A.1).

${ }^{b}$ Assumption: Only ruminant meats (beef and mutton) are served as part of the meat 1 and meat 2 dishes.

${ }^{c}$ Assumption. Only pork, fish, and poultry are served as part of the meat 1 and meat 2 dishes. 
Figure A.2. Share of meat 2 dishes sold across period by type of meat offered, treated restaurant

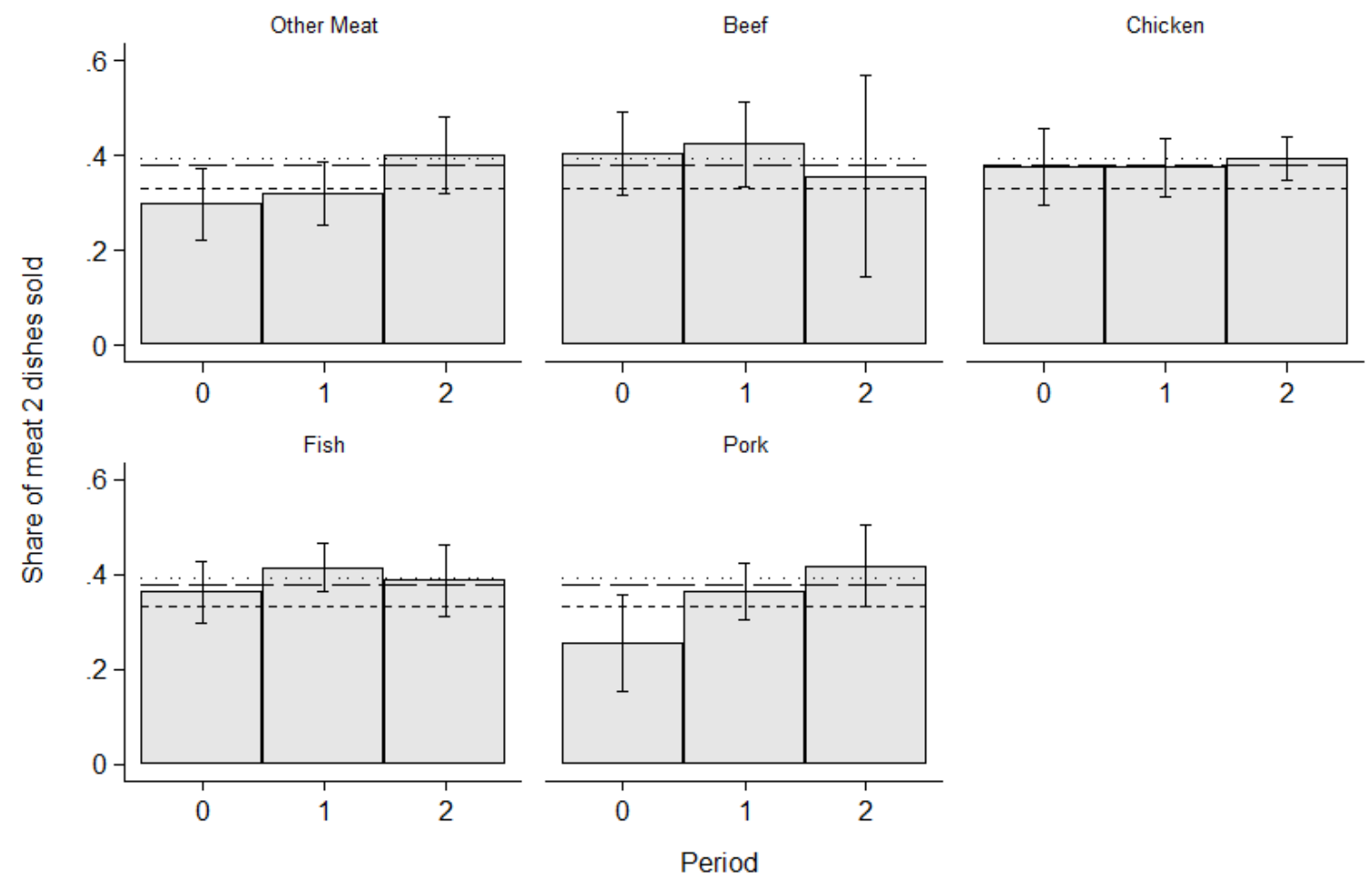

Note: The short dashed lines represent the mean share of meat 2 dishes sold in period 0 ; long dashed lines, the mean share sold in period 1; and dotted lines, mean shares sold in period 2. Error bars represent 0.95 confidence intervals around the mean for each type. 